\title{
Introducing sexuality within family planning: The experience of three HIV/STD prevention projects from Latin America and the Caribbean
}

Julie Becker

Elizabeth Leitman

Mahmoud F. Fathalla

Follow this and additional works at: https://knowledgecommons.popcouncil.org/departments_sbsr-pgy

Part of the Community Health and Preventive Medicine Commons, Family, Life Course, and Society Commons, Gender and Sexuality Commons, International Public Health Commons, Public Health Education and Promotion Commons, and the Women's Health Commons How does access to this work benefit you? Let us know!

\section{Recommended Citation}

Becker, Julie, Elizabeth Leitman, and Mahmoud F. Fathalla. 1997. "Introducing sexuality within family planning: The experience of three HIV/STD prevention projects from Latin America and the Caribbean," Quality/Calidad/Qualité no. 8. New York: Population Council. 


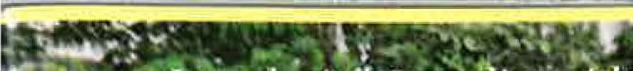

Introducing Sexmalinguive

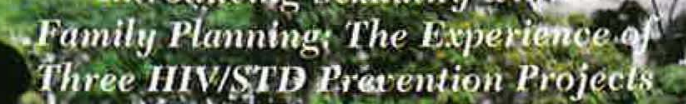

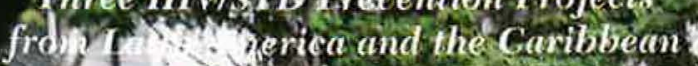
froy
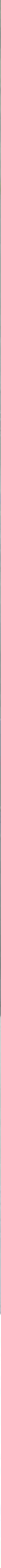

O5 DEZ MANDAMENTO5 DA LUTA CONRRA A

\section{AIDS}

AMAR A VIDA 5DBRE TODO5 AL [ONVEASAR PREVIAMENTE COM 5EU PARCEIRD 50BRE SEXO SEGURD RESPEITAR A5 DIFERENTES RIENTAC ${ }^{-} E$ EEXUALS, TAANSAR 5EMPRE COM NĀO ENGRAVIDAR SENDO HIV NĀ̃ USAR OREGAS PREJUUDIC ALS A SAÚDE, 
Quality/Calidad/Qualité, a publication of the Population Council, highlights examples of family planning and reproductive health programs that are providing unusually high quality care. This series is part of the Council's Robert H. Ebert Program on Critical Issues in Reproductive Health which, through scientific and practical efforts, seeks to improve and expand the scope and quality of reproductive health care. The philosophical foundation of the program, and of this series, is that women and their partners have a fundamental right to respectful treatment, information, choice and follow-up from reproductive health care providers. The pamphlets reflect one of the four main thrusts of the program: enhancing the quality of family planning programs.

Projects are selected for documentation in the Quality/Calidad/Qualité series by an Advisory Committee made up of individuals who have a broad range of experience within the field of reproductive health and are committed to improving the quality of services. These projects are making important strides in one or more of the following ways: broadening the choice of contraceptive methods and technologies available; providing the information clients need to make informed choices and better manage their own health care; strengthening the quality of client/provider interaction and encouraging continued contact between providers and clients; making innovative efforts to increase the management capacity and broaden the skills of service providers at all levels; expanding the constellation of services and information provided beyond those conventionally defined as "family planning;" and reaching underserved and disadvantaged groups with reproductive health care services.

None of the projects documented in the series is being offered as a model for replication. Rather, each is presented as an unusually creative example of values, objectives and implementation. These are "learning experiences" that demonstrate the self-critical attitude required to anticipate clients' needs and find affordable means to meet them. This reflective posture is exemplified by a willingness to respond to changes in clients' needs as well as to the broader social and economic transformations affecting societies. Documenting the critical choices these programs have made should help to reinforce, in practical terms, the belief that an individual's satisfaction with reproductive health care services is strongly related to the achievement of broader health and population goals.

Publication of this edition of Quality/Calidad/Qualité is made possible by support provided by the Ford Foundation, the John D. and Catherine $\mathrm{T}$. MacArthur Foundation and the Swedish International Development Authority (SIDA).
Statements made and views expressed in this publication are solely the responsibility of the authors and not of any organization providing support for Quality/Calidad/Qualité. 


\title{
Introducing Sexuality within Family Planning: The Experience of Three HIV/STD Prevention Projects from Latin America and the Caribbean
}

\author{
by Julie Becker and Elizabeth Leitman \\ Introduction by Mahmoud F. Fathalla
}

\section{Introduction}

On reading this report about introducing sexuality within family planning, I recalled an interesting encounter in India several years ago. I was participating in a scientific meeting on family planning and I was approached by a group promoting a "novel" contraceptive method. They claimedand they were right - that the method can be 100 percent effective, is completely free from known side effects, can be used by both men and women, and offers complete protection from sexually transmitted infections. It can be used by anyone and there are no contraindications to its use. The method, at the time, cost only thirty-five rupees (about one U.S. dollar).

The promoters were disappointed that, in spite of all these advantages, the method was not selling. The brand name was "The Joy of No Sex," and it preached complete abstinence. The onetime cost was for a little booklet that taught some yoga exercises to help with compliance with the method. Apparently, when you stand on the head end of your body for a long time, you cannot think much about the other end! The family planning movement did not go as far as advocating "The Joy of No Sex," but for a long time it chose to ignore the reality that sex has got a lot to do with it. Family planning is about sexuality. It is meant to allow women and men to enjoy mutually satisfying sexual relationships without the fear of unwanted pregnancy.

Although it contradicts what some theologians may like to think, the dissociation of sex from reproduction in the human species was a purposeful evolutionary act of nature. In the evolution of homo sapiens, the temporal relationship between sex and reproduction has been completely severed. In our fellow mammals, the female will only be attractive to the male and receptive to his advances if she is ovulating and ready to conceive. In our fellow primates, the female never fails to advertise the fact that she is ovulating-the external sexual organs undergoing a change in size and color that is clearly visible-making her sexually attractive to the male. At other times, she will have little or no appeal for him nor will she herself have any interest in him.

The sexual receptivity and attractiveness of the human female has completely been emancipated from hormonal control. The human female has also succeeded, through evolution, to hide completely all external evidence of ovulation. Sex was meant by nature for its own sake, not just as a tool for reproduction. With the increasing adoption of the small family norm, sex is increasingly becoming an important component of our psycho-social well-being and less and less a tool of reproduction.

Unfortunately it took the fatal pandemic of HIV infection for the family planning movement to begin to wake up to the realities of people's sexual lives. But even then, it was not easy for a mostly demographic-driven movement to see the point. HIV and sexually transmitted infections can be 
considered-fortunately by few-as contributing to the easing of the world population problem. Indeed, two of the most "successful" female tubal occlusion programs worldwide are, in fact, Chlamydia trachomatis and Neisseria gonorrhoea infections. These diseases are not troubled by the need for informed consent: the woman is sterilized without her even knowing about it!

But beyond recognition of the need to face the realities of people's sexual lives in light of the global epidemic of sexually transmitted infections, what the family planning movement needed to do was to put people, rather than population, at the center stage. It needed a change in focus from "counting the people" to "people count." It needed a shift from demographic targets to individual needs. It needed a wide-angle lens to look at the totality of sexual and reproductive health needs.

Despite arguments about the potential dilution of already limited resources and the inability of family planning services to take on additional tasks, the consensus is now building that sexual and reproductive health care should be an integrated package at the level of policy, management, and administration - as well as at the level of service delivery. The Oxford Dictionary defines the word "integrate" as to "complete (as an imperfect thing) by addition of parts; combine (parts) into a whole." Integration, therefore, should be distinguished from what may be more appropriately called "bundling" of services. The verb "bundle" (commonly used in computer jargon) is defined as to "tie in, make up into, a bundle; throw confusedly in to any receptacle." When services are simply combined or "bundled" together in one way or another, the result is not integration. When services are combined or joined together as a strategy to provide a more complete package, with the client at the center of and as the focus for services, this is "integration."

Sexual and reproductive health is about men's and women's relationship to each other; although the issues are often of more concern to women. Women have less power in negotiating sexual relationships and they are the ones who get pregnant. By definition, sexually transmitted diseases (STDs) affect both men and women, but the disease burden on women is much heavier. A recent World Bank report ranked sexually transmitted diseases as the second major cause (after maternityrelated causes) of the disease burden in young adult women in developing countries. Among males of the same age group (15-45), STDs were not even among the first ten causes of the disease burden. ${ }^{2}$

For a mix of biological and social reasons, women are more likely to be infected by STDs, are less likely to seek care, are more difficult to diagnose, suffer more severe disease sequelae, and are more subject to social discrimination and repercussions. The most effective method available for protection against STDs, the condom, is controlled by men-by definition, women cannot "use" condoms. An effective method of protection that a woman can use without the need for her partner's cooperation simply does not exist as yet. The fact that women have more at stake in sexual health than men do does not, however; mean that men can be left out. Men have sexual health needs too, and their sexual health is important for women's sexual health. Men can play a positive role in promoting the sexual and reproductive health of their partners. But, unfortunately, many men are either not informed of their role in, or exercise an adverse influence on, women's health. ${ }^{1}$

Change is never easy and it is particularly difficult when it means, or necessitates, changing people. It is easier by far to impart new knowledge to service providers or to help them acquire new technical skills. Much more challenging is actually changing their attitudes, particularly when the issue is a subject such as sexuality, and when their effective involvement requires them to clarify and possibly re-evaluate their own beliefs and behavior in such a sensitive area. But changing attitudes is what counts most. Attitudes are never simply the addition of knowledge and skills. There is a multiplying factor. If the attitude to sexual safety and expression is zero, the result of whatever amount of knowledge and skills imparted can still be zero.

Change takes leadership, innovation, and risk taking-which is just what three family planning associations in the Latin American and Caribbean region ventured to do when they sought to introduce sexuality within family planning. They ended up, and rightly so, introducing family planning within sexuality. They deserve full credit for what they did, and their experience is worthy of reading and learning from. 


\section{Background}

Scene 1, a family planning clinic (1993): It's a rainy Wednesday morning. Patricia, a street vendor, arrives at the urban clinic seeking a family planning method for the first time. After a short wait, a counselor warmly greets the young woman, repeats her name, and leads her to a private area where they sit down together.

The counselor asks Patricia a series of questions and listens attentively to her responses. Patricia says that she has never used family planning, but hears from a friend that the pill is a good method. After the counselor restates what Patricia says to confirm that she understands, she asks her if she knows about other family planning methods.

When Patricia indicates that she only knows a little, the counselor describes each method in detail, explaining how each is used, how to insert a diaphragm, what to do if you miss a pill, what to do if you miss two. When she describes the condom, she shows the young woman a small plastic package. She says that condoms are good to use if you forget to take a pill, and it is important to use them for a while when you first start taking the pill until it becomes effective. The counselor then shows her the different pills available and discusses the price. Patricia leaves the clinic with a three-month supply of pills.

Scene 2, same clinic (1996): It's a rainy Wednesday morning. Patricia, a street vendor, arrives at the urban clinic seeking a family planning method for the first time. After a short wait, a counselor warmly greets the young woman, repeats her name, and leads her to a private area where they sit down together.

The counselor asks Patricia a series of questions and listens attentively to her responses. Patricia tells the counselor that she had never used family planning, but her sister-in-law uses the pill and she thinks that she would like to do the same. The counselor spends a few minutes exploring Patricia's life and individual situation. They discuss her family, her current partner, her previous partners, and her level of satisfaction with her sexual life. They discuss the fact that her husband travels for work. The counselor asks her if she thinks he might have other partners when he travels and Patricia admits that he probably does. She and the counselor then discuss the fact that this could be putting her at risk of contracting human immunodeficiency virus (HIV) or another sexually transmitted disease (STD). They discuss what she knows about HIV and STDs, and the counselor clarifies misinformation, making sure to describe the types of sexual activities that are safe and unsafe.

The counselor reviews the benefits of condom use, and demonstrates, on a penis model, how to use a condom correctly, emphasizing that condoms can be highly effective against pregnancy, HIV and STDs when used consistently and correctly. She mentions some ways to make condom use more appealing to a man by, for example, putting it on for him and massaging his penis while doing so.

The counselor asks Patricia whether she has ever had an STD or any other infection and then inquires as to whether she has ever discussed HIV with her husband - or whether they have in fact ever discussed their sexual life. Patricia admits that they have not, but says she has wanted to. She and the counselor then discuss strategies for bringing up the subject in a non-threatening way.

Before the session ends, the counselor briefly reviews the available family planning methods, emphasizing that it is necessary to use a condom with all other methods to protect against HIV and STDs. In the end, Patricia selects the pill as her method and the counselor explains in detail how to use it correctly. Patricia leaves the clinic with a three-month supply of pills, and a free sample of condoms to try.

000000000

These "typical" family planning counseling sessions are composite descriptions of sessions that were observed shortly before (1993), and two years after (1996), implementation of a new project to integrate HIV/STD prevention into the existing family planning programs and services of three family planning associations (FPAs) affiliated with the International Planned Parenthood Federation, Western Hemisphere Region (IPPF/WHR).

By 1996, the typical counseling session had evolved from mainly informational into a real exchange between counselor and client that explored the client's needs within a sexual and reproductive health context. This edition of Quality, Calidad, Qualité, highlighting the experiences of BEMFAM/Brazil, ASHONPLAFA/Honduras, and FAMPLAN/Jamaica, explores how the staff of these three family planing associations (FPAs) 
have been malking the transition to a more clientcentered, sexually explicit approach to providing family planning services, and what the transition has meant to them and their clients.

\section{Evolving Programs and Attitudes of the Western Hemisphere's Family Planning Associations}

Throughout the history of family planning, most programs have concentrated almost exclusively on the delivery of contraceptive services. Initially introduced in clinics, services later were extended to community-based distribution and commercial social marketing programs. However, despite this movement outside of the clinic, services remained based on a medicalized model where clients' broader sexual and reproductive health needs were rarely addressed nor were issues of sexuality discussed. Those providing family planning services often failed to consider the realities of clients' sexual lives or the social and cultural context in which sexual activity occurs. Motivated by population control targets, many programs emphasized the use of longer term, "more effective" family planning methods, such as IUDs and sterilization. Under these circumstances, condoms were rarely mentioned, let alone made a priority method.

In recent years, the family planning field has moved toward a greater awareness of gender issues and the importance of quality of care; now it seeks to broaden its focus to incorporate sexual and reproductive health. The International Conference on Population and Development (ICPD, 1994) in Cairo reaffirmed the idea that sexual and reproductive health extends beyond the provision of family planning services to encompass a broader range of care, including the prevention and treatment of reproductive tract infections (RTIs) and STDs, including HIV. Determining how to implement this perspective, however, has presented a challenge to both the management and the staff of family planning programs alike.

When the AIDS epidemic began, most family planning associations in the Western Hemisphere Region did not want to be involved. Many perceived the epidemic as only affecting marginal populations, not family planning clients, who were considered to be married women in long-term relationships. Even as the realization grew that the epidemic was increasingly affecting all women-including those in supposedly monogamous, long-term relationshipsthere remained the fear that offering HIV/STD services would frighten away or in some way offend family plamning clients, and thus dilute the mission of the FPAs. Similarly, they feared that the cost of integrating HIV/STD services and family planning would be prohibitive, potentially thwarting efforts to increase income self-sufficiency and sustainability. In the late 1980s and early 1990s, those FPAs that did carry out HIV/ STD-related activities mainly addressed "high risk groups" such as gay men, commercial sex

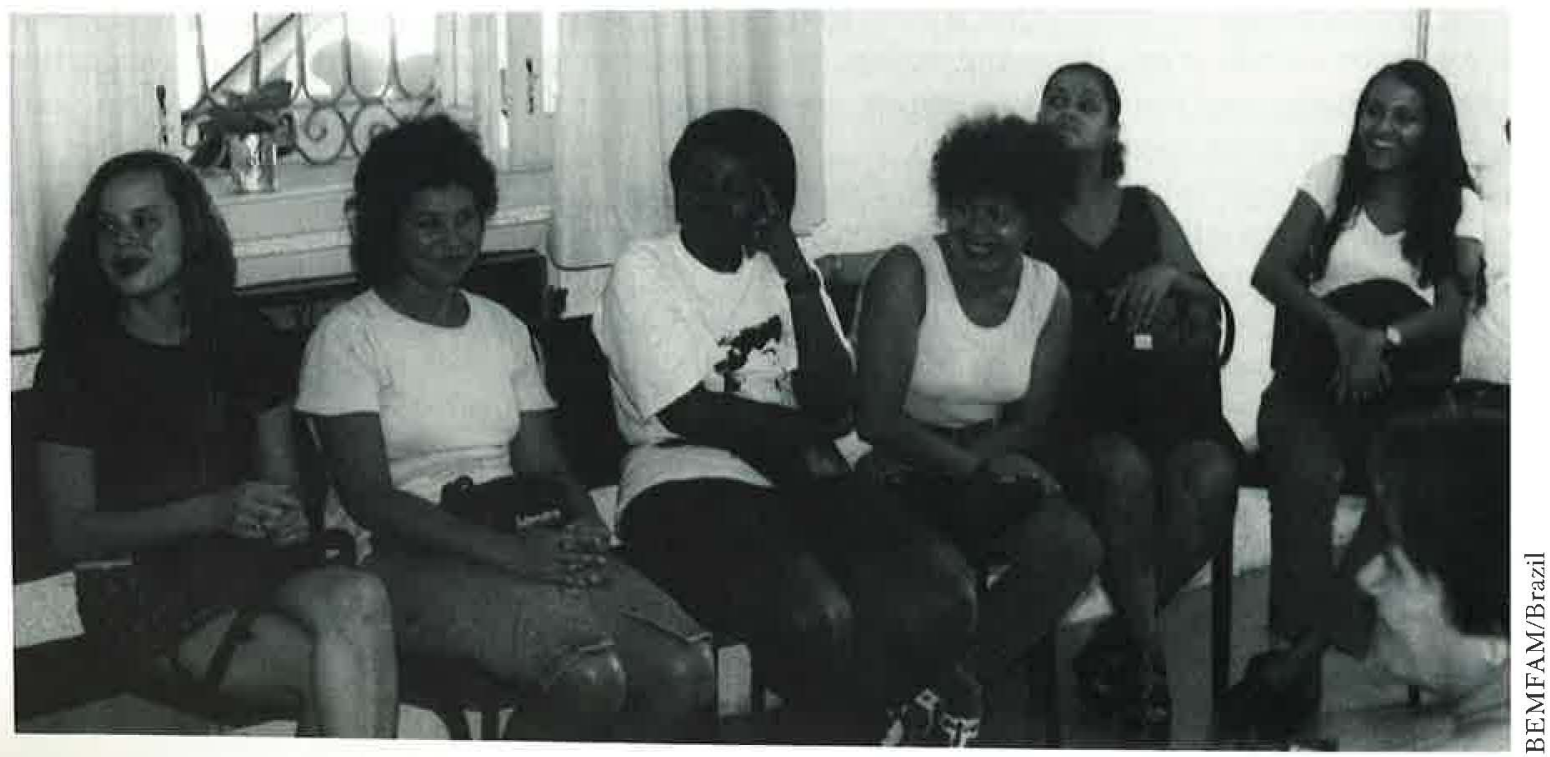


workers, or general populations outside their own clinics. Few brought up the topic with their own clientele or offered services under their own roofs.

Beginning in the late 1980s, the overarching theme of IPPF/WHR's regionally supported HIVprevention activities was reducing the stigma associated with AIDS prevalent at the time, and helping FPAs to recognize the increasing threat the epidemic posed to women in long-term relationships-namely their clients. Although these small-scale endeavors had limited impact, they nonetheless paved the way for the development of a more comprehensive, integrated approach.

In 1992, the United States Agency for International Development (USAID) ${ }^{2}$ provided funding to IPPF/WHR to develop a pilot project to integrate HIV/STD prevention in the programs and services of three family planning associations in Latin America and the Caribbean: BEMFAM/ Brazil, ASHONPLAFA/Honduras, and FAMPLAN/Jamaica. This new support provided an opportunity to develop full-scale integrated programs within these FPAs.

When the project began, there was little experience integrating HIV/STD prevention and family planning, so IPPF/WHR and the three FPAs began the process of defining and developing HIV/STD/family planning integration programs without the benefit of models to follow. This was actually positive because it allowed each FPA to develop a unique program based on its own service structure, the perceived needs of its clients, and the particular interests and ideas of its management and staff. As these programs mature over time, it is hoped that other FPAs in the region - as well as family planning programs more broadly - will be able to benefit from what has been learned. For despite linguistic, cultural, and programmatic differences between the three FPAs, many of the issues they and their clients face are remarkably similar.

\section{INITIATING THE PROCESS OF CHANGE}

\section{Counseling and Education Before the Project}

By 1993, most front-line staff in the regional FPAs already possessed strong educational and counseling skills, demonstrating empathy, listening actively, and truly reflecting on the expressed needs of each client. Nonetheless, they utilized these skills narrowly, with little attention to sensitive issues such as sexual practices and personal relationships. Although some group education and other outreach work with clients was highly participatory, individual "counseling" was more often than not the one-way provision of information by the "counselor" to the client. Many FPA staff did not feel comfortable discussing issues related to HIV, STDs, and sexuality. They tended to present condoms exclusively as a back-up method as opposed to a valid option for family planning and HIV/STD prevention.

When the project began, most FPA staff were aware of the existence of AIDS, but few possessed in-depth knowledge of the disease, nor did they tend to link HIV/STDs with family planning and sexuality. Many held misconceptions about how HIV is transmitted, and few were aware that STDs could be asymptomatic. A family planning counselor describes the approach to counseling typically taken at her clinic prior to the new program:

Typical services included advantages and disadvantages of family planning methods, giving the client the best method, and, well, we didn't enter into prevention, but we did mention that they had to take care of themselves. We sometimes mentioned protecting oneself not only against pregnancy but diseases as well, but it wasn't done with love, it wasn't done to help people change their opinions, it was simply information. It was just advice that you had to avoid it. We didn't really discuss it, only if the client asked. It wasn't effective counseling.

\section{-Thesla Bustillo, ASHONPLAFA/Honduras}

At the time, this limited scope of counseling seemed appropriate for family planning but, when HIV/AIDS came into the picture, it was soon apparent that this topic could not be effectively addressed without taking a broader sexual health approach. Addressing AIDS requires a frank discussion of sexuality and sexual behaviors and a more personalized approach to counseling. Staff have found it impossible to help clients have safer sexual relations without first addressing the underlying factors that influence an individual's 
ability to make decisions about and control his or her sexual life. This new emphasis on sexuality is, in turn, changing the way family planning services are being rendered.

The goal of the program was not to add HIV/ STD prevention as simply another element of family planning services. Rather, it was to improve the overall quality of services by changing the manner in which they are provided, not just merging two types of services-family planning and HIV/STD prevention-or housing two separate services under the same roof. The intent of the project was to fundamentally alter the nature of the client-provider interaction.

\section{Staff Motivation for Change}

While the decision of each FPA to take on an HIV integration project at the institutional level was essential, and the training provided to staff served to launch the process, it was in fact a sense of urgency about the AIDS epidemic itself that actually made the shift in staff attitudes and approach possible. As one family planning counselor recounts:

One of the factors [that motivated this change] more than anything was the reality that we are living. We cannot deny the fact that in my city, San Pedro Sula, we have the highest rate of AIDS. Now, every day, I'm with a person who, if they don't have AIDS, or their husband doesn't have AIDS, they have some cousin, uncle, or brother with AIDS or HIV. I have had to see so many cases that it's no longer strange. We have to go beyond [what we are doing] to protect our people, our country, and ASHONPLAFA itself.

\section{-Yolanda Ruiz ASHONPLAFA/Honduras}

By 1993, AIDS was a reality, not a rumor. In addition to inspiring staff to take action, the epidemic itself also created client demand for information, counseling, and services related to HIV/AIDS. Here an outreach worker from FAMPLAN/Jamaica describes the concern and fear behind clients' increasing desire for assistance:

Before this girl died from the AIDS virus, the HIVIAIDS, when you go to them boys, they didn't really want to hear what you have to say. But you see, since they know that this girl died, and they hear she talked about the amount of partners that she usually have, everybody is so frightened.

\section{PROJECT DEVELOPMENT AT THE INSTITUTIONAL LEVEL}

Each of the three FPAs is very different in terms of size and structure. Accordingly, each has developed a somewhat unique design for their HIV/STD and family planning integration projects, yet incorporated some common elements. BEMFAM/Brazil has hundreds of staff working in eight clinics and over one hundred health posts; Honduras has five clinics plus a community sales program; while FAMPLAN/Jamaica (with approximately twenty staff including administration) has only two small clinics and a rural outreach program. All three FPAs, however, serve both urban and nonurban, middle-class and poor populations. Since the project's inception, the three FPAs have had opportunities to exchange experiences, and they have made modifications and adopted elements based on one another's programs.

The course of development for each project was determined, in part, by responses to needs assessments conducted by IPPF/WHR staff and FPA management. These included formal and informal interviews with staff and clients, as well as observations of counseling sessions. Using this information, IPPF/WHR and FPA staff worked together intensively to determine each FPA's priorities, given the existing structure of their programs, resources, staffing configuration, and perceived needs.

\section{Step One-Staff Training}

In each of the FPAs, a first step in initiating the new projects was staff training carried out by a combination of in-country consultants, FPA staff, and IPPF/WHR staff, depending on the needs and resources of the particular FPA. (Over time, each FPA has developed some level of inhouse capability to provide training to its own staff members.)

In all three countries, a wide variety of staff — not just counselors and educators, but physicians, nurses, administrative staff, and support staff, including drivers and cleaners-participated in training sessions. Initial trainings, usually two 


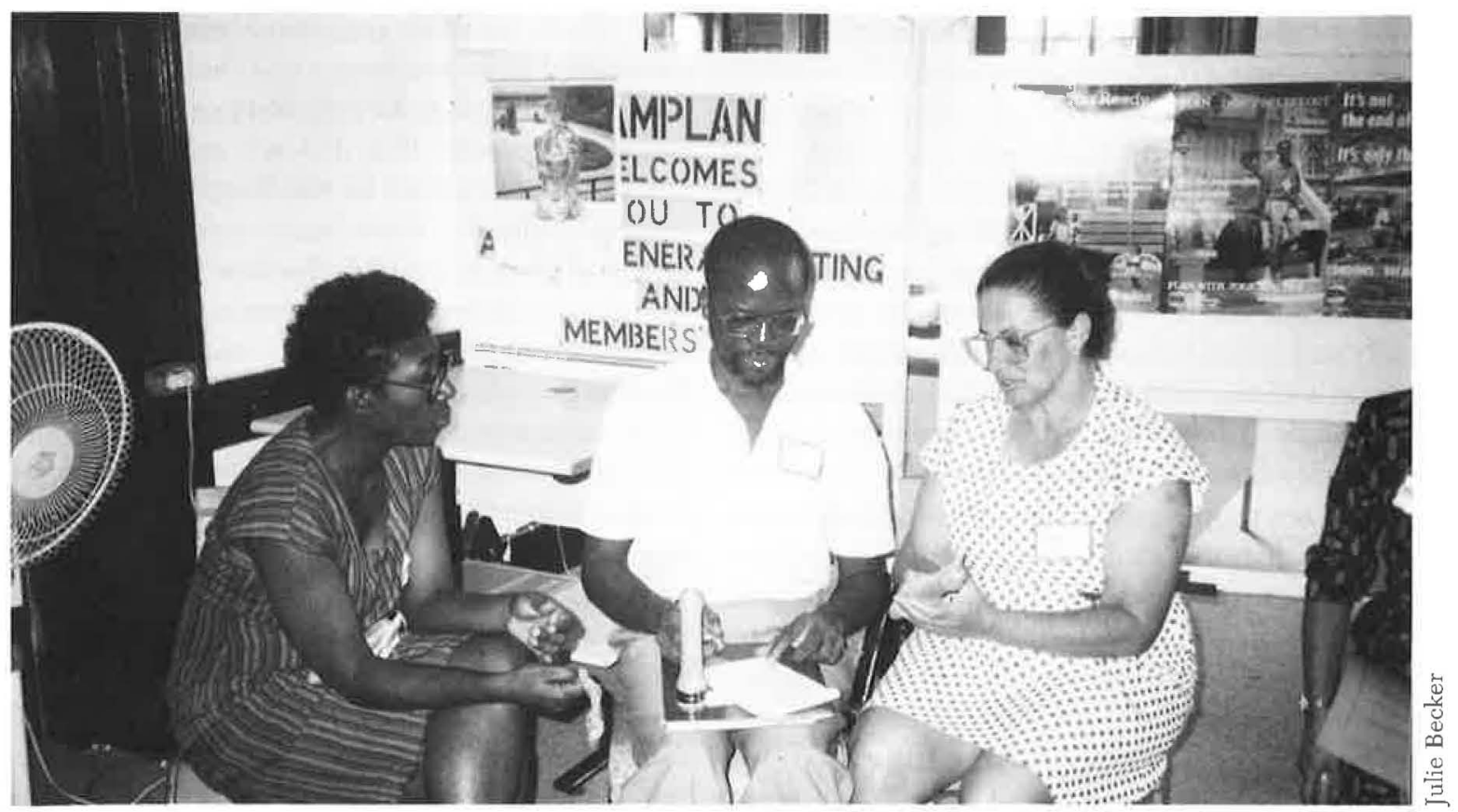

to three day-long sessions, focused on basic information about HIV/STD, sexuality, and related education and counseling skills. Subsequent trainings helped staff understand and define for themselves the broader concept of sexual and reproductive health; delve more deeply into issues of sexuality; and learn new skills for communicating with clients about such sensitive issues. Sessions also included analysis of issues related to gender and power and development of skills to help clients communicate and negotiate with their sexual partners. Specific trainings in specialty areas were held for smaller groups of staff. For example, physicians and nurses received training in STD diagnosis and treatment; staff who work with groups received training in group facilitation skills; and staff responsible for facilitating women's discussion groups received training in a more specialized type of group work methodology.

In order to help staff become more comfortable communicating about sexuality, they were prompted to reflect upon their own feelings and experiences, which helped to create a level of selfawareness needed to positively affect their interactions with clients. As one physician in Brazil reflected upon her experience:

You can even have the knowledge, have taken a thousand courses and prepared yourself, but you have to want to do it. I think that what is important about the course...is this-first becoming aware and sensitized. Previously acquired knowledge is worthless if I am not sensitized.

-Dr. Vania Bastos Petti, BEMFAM/Brazil

\section{TRAINING THEMES}

Although training sessions in each FPA were geared toward the specific needs, levels of knowledge, and skills of the participants, the following are some themes that were common to all three programs.

\section{Comfort with Sexual Language}

In order to effectively talk with clients about sexual and reproductive health, it is necessary for staff to become comfortable with the language of sexuality. Participants from different countries, or even within the same FPA, often varied tremendously in their level of comfort with sexual language. Therefore, training sessions usually began with exercises to help participants verbalize a variety of terms describing sexual acts and sexual anatomy, using both formal language and local slang. These exercises often involved an exploration of the differences between the words used by professionals and those known to clients, which words are considered acceptable or unacceptable, 
and what terms best meet clients' needs in any given setting.

\section{Clarification of Values}

Although many FPA staff had received previous training in values clarification, the level of knowledge and sensitivity to issues related to sexuality and sexual behavior required to address HIV, along with the tremendous level of stigma associated with AIDS, called for a much more in-depth exploration of deep-seated values.

One training exercise called for staff to examine a list of sexual behaviors such as oral sex on a woman, oral sex on a man, group sex, anal sex, extramarital relations, and prostitution. Participants were asked to decide whether each behavior was acceptable for themselves, for others, or simply not acceptable. Staff then discussed how it feels to have someone else decicle that an activity in which they themselves engage is unacceptable. In other exercises, staff listened to valueladen statements such as: "People who have sexual relations with members of their own sex are abnormal;" "Women without education are incapable of making their own decisions about their reproductive and sexual life;" or "Having more than one sexual partner at a time is acceptable." Participants were then asked to decide if they agreed or disagreed with the statement, and then to try to convince those with an opposite belief to accept their point of view.
These exercises were very revealing as staff uncovered their own biases and challenged those of their colleagues. As members of the communities and cultures that they serve, FPA staff often reflect the values of the larger society. For example, during these exercises, some staff equated certain sexual behaviors with prostitution or homosexuality and expressed a judgmental attitude about the behaviors and the individuals who engage in them. At FAMPLAN/Jamaica, staff encountered difficulty in discussing, let alone accepting, what they considered to be deviant behavior, such as anal sex. However, once they agreed that this is indeed a practice in which both men and women engage in their country, in spite of the associated stigma, they recognized the importance of addressing it in their counseling work.

One staff member who felt strongly that oral sex was abnormal behavior had difficulty separating her own values concerning the behavior from her discussion about what was safe or unsafe in terms of transmission of HIV/STDs. Her colleagues' efforts to help her separate the two issues proved futile. Yet, despite her inability to look beyond her own personal values during the workshop, shortly thereafter she began actively teaching clients how to cut a condom in half to use it for protection during oral sex on a woman. Clearly, she did hear, and eventually came to accept, the idea that it was her responsibility as a health professional to address these issues despite her personal values.

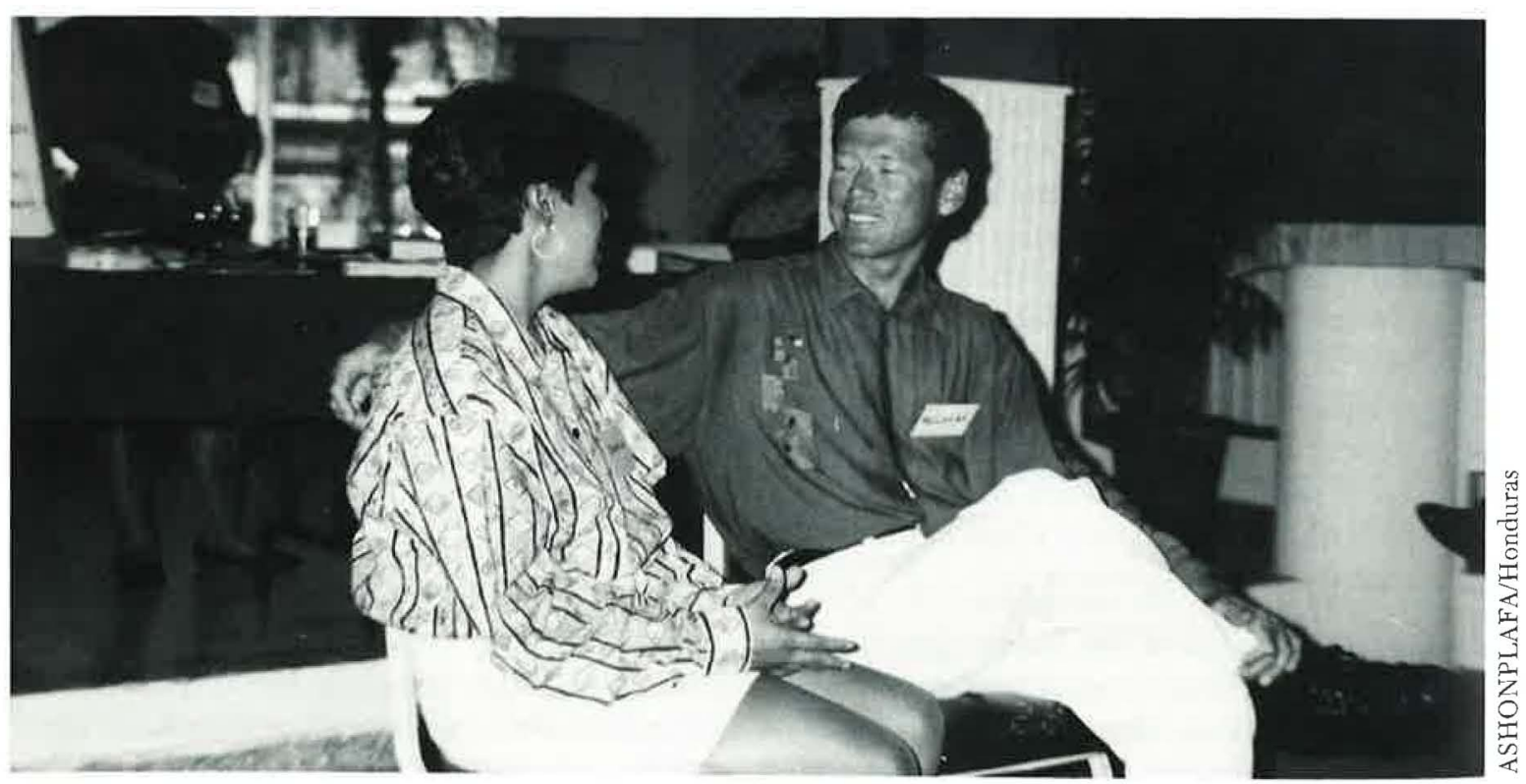




\section{Sexual Development}

In addition to providing factual information related to sexuality, many training exercises helped participants recall their own experiences learning about sex and how that affected their sexual development emotionally and physically. One exercise asked staff to close their eyes and reflect upon how they first learned about sex in their childhood and the circumstances around their first sexual feelings as they grew up. They were asked to remember the emotions they felt as they grew and learned. In Honduras, staff shared a wide range of remembered feelings, both positive (happiness, curiosity, awakening sensations, desire, and love) and negative (anxiety, fear, shame, disgust, and sadness). This helped staff to draw upon their own experiences as a means of better understanding their clients' feelings about sexuality.

Sexuality is the one area where staff at all three FPAs consistently expressed a need for additional training in terms of both technical information and skills in handling sensitive issues. One exercise asked participants to write out and submit anonymous questions about sexuality, which revealed very fundamental concerns that individuals may not have felt comfortable expressing aloud. Questions posed in one workshop included:

- Can you practice anal sex with a female partner?

- Why did I bleed a lot during my first sexual relation?

- Is masturbation bad?

- Is oral sex satisfying?

- Are there people who, although stimulated sexually by their spouse, do not have orgasms? What is this due to?

- Why do some women have fear at the moment of penetration?

\section{Defining Sexual and Reproductive Health}

In some training sessions, staff explored the variety of meanings behind the terms "sexual health" and "reproductive health" in order to come to a common understanding of the concepts in the context of their own communities and work. During a training in Honduras, participants defined sexual health as: "The acceptance of our own sex and general health... Having a positive attitude, we will have sexual health free of contagion with HIV/STDs... To have sexual health, we have to be physically, psychologically, and emotionally well." Under reproductive health, they added "The well-being of the couple and the individual, mentally, socially, emotionally, and economically.. These are optimal conditions for all human beings to reproduce."

A physician from BEMFAM/Brazil reflected on what it means to provide more comprehensive sexual and reproductive health services, noting that:

Someone can be a good professional, knowing how to insert an IUD correctly, knowing exactly which medication should be given for gonorrhea, but this [broader approach] involves viewing a person as a wholetending to a client from a holistic perspective of overall health and well-being. I feel that BEMFAM's trainings served to give people that vision.

-Dr. Roberto Dias Fountes

\section{The Client's Sexual Life and Risk Perception}

An important aspect of the training was to help staff build skills for exploring their clients' individual circumstances, including their sexual lives. Using role playing, staff practiced how to help clients articulate their true concerns about their reproductive and sexual lives, and determine for themselves their own level of risk in terms of HIV infection. One role playing exercise calls upon a participant to take the part of a counselor who knows nothing about the client's situation. Another participant, who plays the client, is given a situation which she/he reveals only upon exploration by the counselor. In one such session in Honduras, participants were asked to explore the following client scenarios:

- A client has deep religious beliefs and is very ashamed. She is concerned about STD and HIV because she suspects that her husband is unfaithful. She will only discuss this with the counselor if she is made to feel comfortable enough to confide.

- An adolescent visits a clinic to ask for 
contraceptive methods. She has been abused sexually by her uncle and is terrified to speak about it.

- A woman whose husband forces her to have anal sex believes that her husband might be homosexual.

In some cases, the "counselor" succeeded in helping the "client" to open up and discuss real feelings. However, when the "counselor" was less successful in revealing the clients' actual situation, all participants helped to analyze the situation, identifying approaches that might have helped the client to eventually articulate her true concerns. Together, staff then defined the types of questions that can aid in the exploratory process.

Other exercises were designed to help staff understand how clients perceive their own risk and the factors that influence these perceptions. Participants took part in role plays about typical situations such as an interaction with a client who has come to the clinic seeking a family planning method but has never really thought about her own risk of contracting HIV. Here the participant playing the part of the counselor was asked to try to understand the client's level of risk perception and the factors that influence her perceptions, then to help her recognize how these factors might put

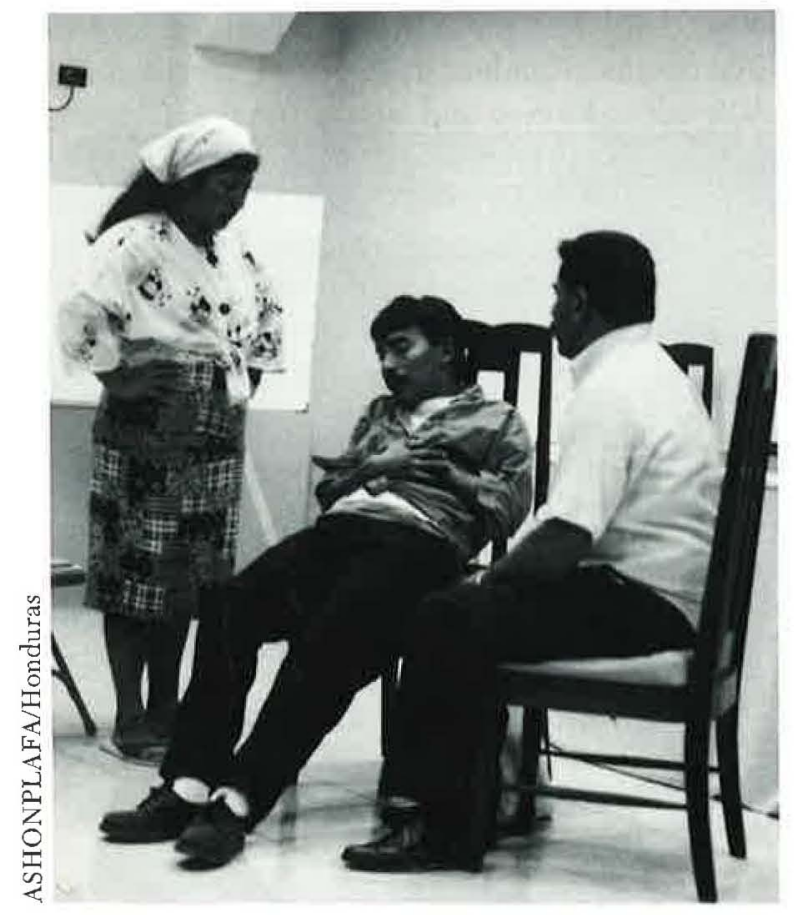

her at risk. By analyzing these role plays together, staff were able to develop strategies to help clients understand and evaluate their own risk.

\section{Gender, Power, and Sexual Relations}

Together staff also looked at the ways in which economic dependency and gender relations can affect clients' reproductive health decisions, practicing ways to help them consider the potential ramifications of their decisions. During a recent training in Honduras, participants made a list of factors that may affect clients' decisions, including fear of pregnancy, fear of ending up alone (losing their partner), fear of domestic violence, religious beliefs, and influence of or coercion by spouses themselves.

Other training sessions helped staff analyze the ways in which societal and personal gender constructions affect the dynamics of sexual relationships. Here exercises included analyzing the factors that can make relationships unbalanced in terms of power and role playing scenarios of sexual communication and negotiation in an unbalanced relationship. In other exercises, staff reflected upon the advantages and disadvantages of being male or female in their own cultural context, and how these social factors played out in sexual relationships.

\section{Safe Sex}

During the training workshops, staff explored strategies for helping clients broach the subject of sexual relations or condom use with their partners. They learned how the timing and circumstances under which the subject is raised can make a difference in terms of what happens next. For example, in Jamaica staff made a list of the excuses people make to avoid using condoms and then devised lists of counterarguments that could be used in the negotiation process. In order to better understand how difficult this can be from a client's perspective, they acted out various situations in which couples might negotiate the terms of their sexual relations.

The trainings explored safe sex in a broad sense-that is, not only in terms of protection from HIV/STD transmission, but also in terms of protection against unwanted pregnancy and 


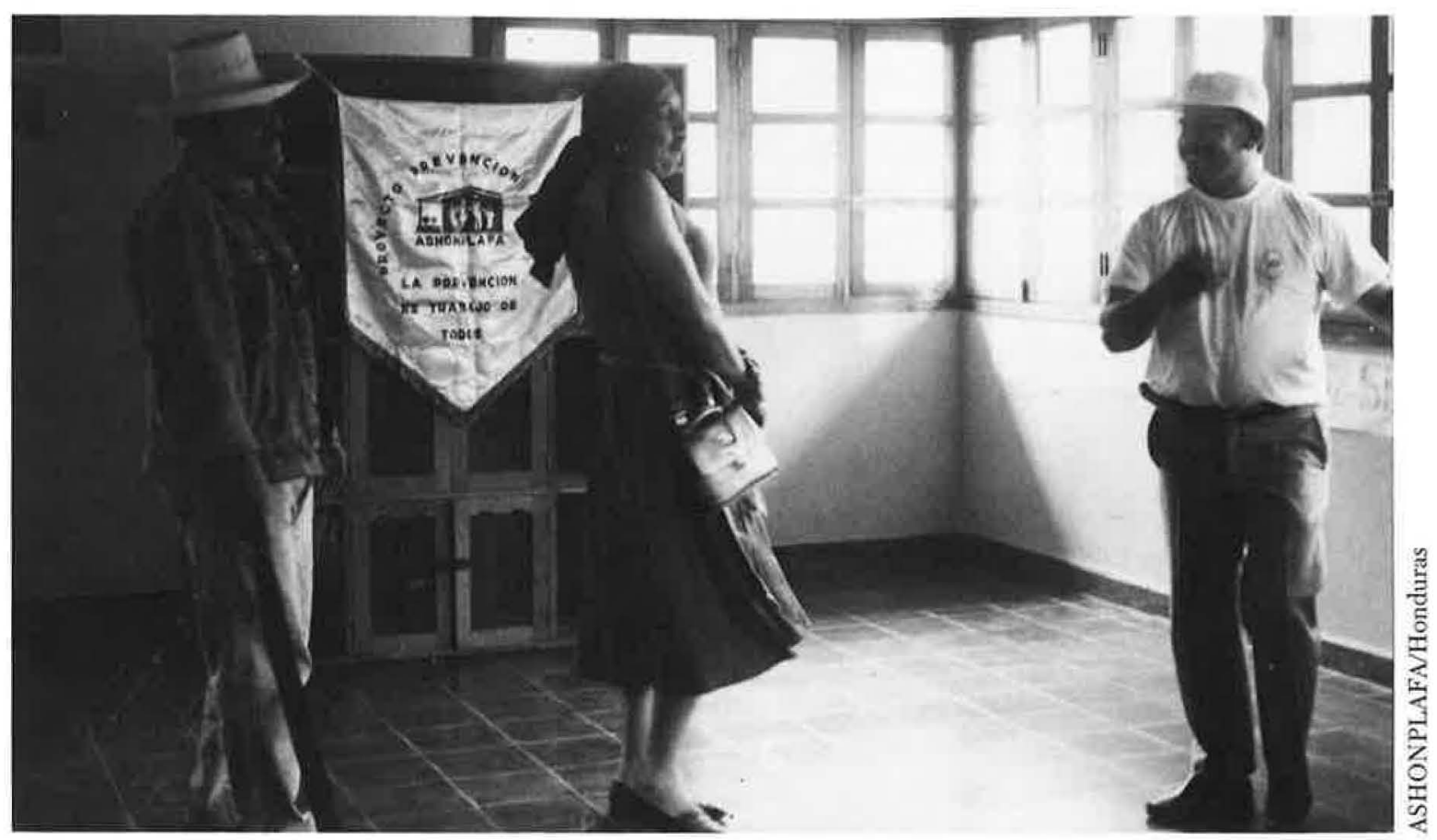

the abuse of power. Participants discussed safe forms of sexual expression and participated in exercises to encourage their creativity in defining forms of sexual expression that do not involve penetrative intercourse. The staff in Jamaica included in their lists of "sexual expressions" activities such as massage, reading poetry, and taking baths together.

\section{Family Planning from a Sexual/ Reproductive Health Perspective}

In these exercises, staff analyzed all family planning methods in terms of not only their effectiveness in preventing pregnancy or STDs, but also their effect on sexual relations and sexual pleasure. They explored issues related to use of condoms alone as a family planning method as well as the possibilities of dual method use-using condoms along with other contraceptive methods.

More specific exercises helped staff to explore their own personal and professional biases against condoms and determine ways to destigmatize use of the method with their clients. Prior to the training, many participants had little or no experience demonstrating correct condom use. So, with the aid of a penis model, they learned everything from opening the package to proper disposal techniques.

\section{Sexually Transmitted Diseases}

A basic understanding of STDs prevalent in each setting, including a review of basic signs and symptoms, has been an important component of training for each FPA. Counseling staff have learned to help clients recognize what is and what is not normal, and to explore each client's history of STDs. They have learned about the dangers of providing IUDs to clients who are at risk of STDs, and about asymptomatic infections-information that was entirely new to many staff. STD training for medical and nursing staff was more in-depth and included clinical recognition of STDs, diagnosis, and treatment.

\section{PROCESS OF CHANGE AMONG PROVIDERS}

I am aware that I am serving my clients with more interest and dedication because I am not talking just about a method, but rather the prevention of disease. And this makes me feel good.

- Thesla Bustillo

It is clear from this statement that this counselor takes great pride in her work. During the 
past three years, staff from ASHONPLAFA/Honduras and their counterparts at BEMFAM/Brazil and FAMPLAN/Jamaica, have witnessed changes in themselves as they have grown both professionally and personally through their new mission at their FPA. They have also witnessed startling changes in the questions and concerns of their clientele as the AIDS epidemic gains momentum and clients respond to the FPA's new approach to service delivery.

Of course, change does not take place over night - it is a process. The story behind these changes begins to emerge in discussions with FPA staff members-program coordinators, counselors, outreach workers, physicians, and nurses - who register genuine enthusiasm when they describe how they go about helping clients with a range of concerns that go beyond simple method selection. For example, a physician from BEM-FAM/Brazil describes how the new program has allowed his role to expand beyond clinical treatment to incorporate clients' emotional concerns as well:

I am sure that at other clinics, probably the majority of them, the physician inserts an IUD as well as I do or prescribes a gonorrhea medication as well as I do. It's not too difficult-you follow procedures, look in a book and there you have it. But the issue of preparing people emotionally...causes us to think differently now, to deal with the emotions of others. Now we work with people's emotions, too. In this regard, we have overcome our prejudices and limitations.

\section{-Dr. Roberto Dias Fountes}

Beyond a new approach to counseling and client interaction, staff describe a new level of selfawareness among both themselves and their clients:

Before we used to talk about methods and we'd arrive at an agreement with a client on a method. But now we go much deeper. We ask if she has an infection... we look for risk factors...we can talk about other things such as sexual relations, about her sex life in general, about her partners, right? There have been times when I've asked clients who takes the initiative in having sex, and how she feels about it...I have discovered that women want more... they want to know more about themselves...

- Yolanda Ruiz

\section{Rethinking Family Planning Methods}

Within this broader focus, providers have changed the way they discuss family planning methods, expanding their explanation of each method to include its relationship to HIV/STD transmission. Staff now highlight the dual benefits of condom use for pregnancy and HIV/STD prevention and they also discuss the option of dual method use-the use of condoms in conjunction with another family planning method. As the Executive Director of FAMPLAN/Jamaica notes:

Issues related to family planning methods and the threat of HIV/STDs have become more complex. Staff now have to discuss the relationship between family planning methods and HIV/STD transmission. Emphasis is placed on the importance of the condom in that regard and the clients can choose whether to use two methods or rely on the condom as a dual protection method.

\section{- Peggy Scott, FAMPLAN/Jamaica}

In the past, staff were also less likely to explore factors that could pose potential complications for IUD use, such as multiple partners and a history of STDs. According to Gloria Flores, a counselor at ASHONPLAFA/Honduras, in the past some women may have received IUDs who should not have because attention was not paid to their risk of STDs. Another staff member in Honduras describes a situation where counseling helped an IUD user better protect herself by also using condoms:

There was this woman, about 33, who had been using condoms as her contraceptive method for about 5 years. Her husband... had been in Choluteca for about-I don't know what she told me-8 or 9 monthswhen she realized that he was involved with another woman up there. When she learned about this she had wanted to "reward him"-her words-to give him a surprise ... to give him the gift of getting an IUD so that he wouldn't have to keep using condoms. She wanted to get the IUD despite the risk that she faced of contracting an STD because of her husband's extramarital affair. And this was a woman with a high edu- 


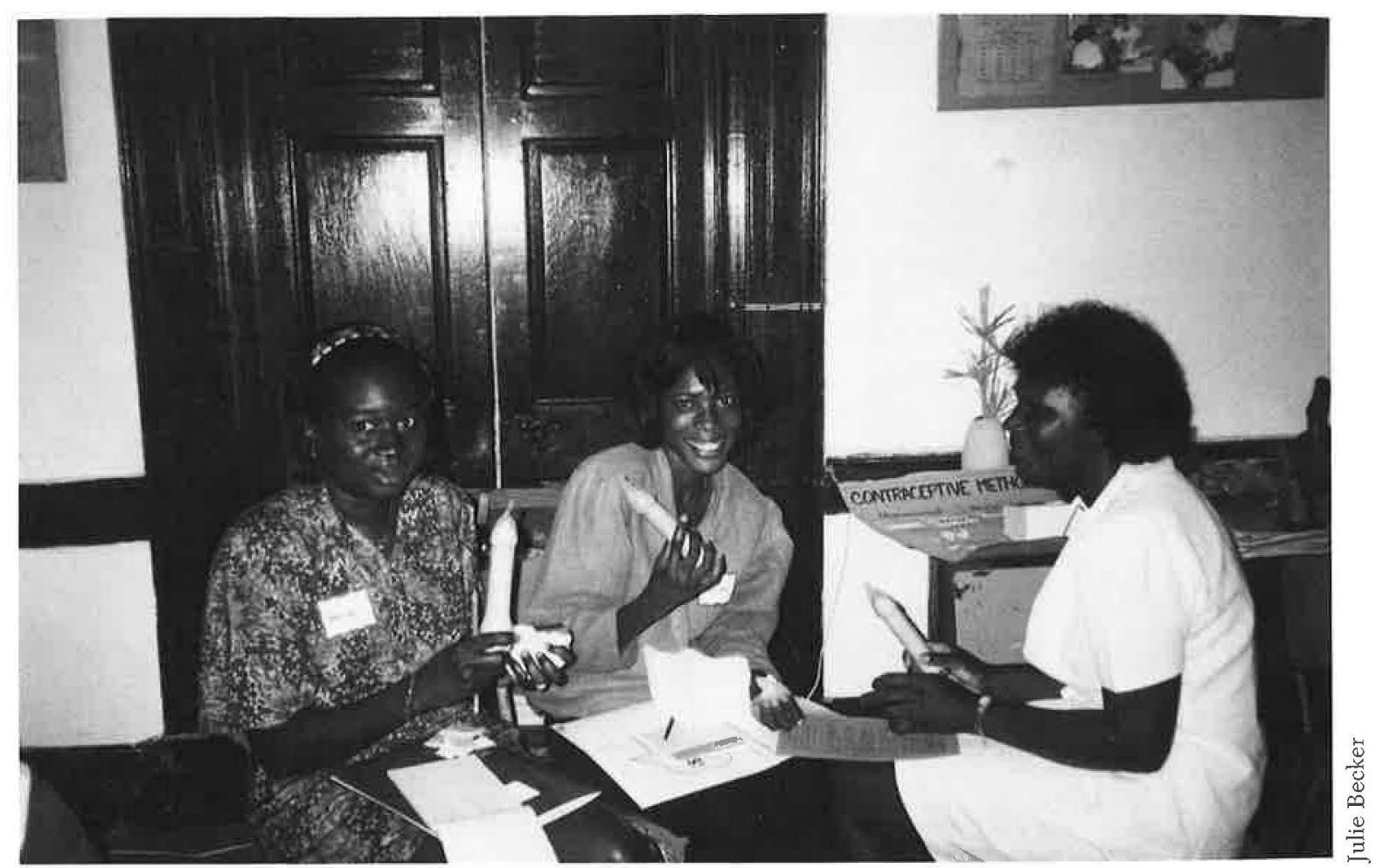

cational level, right? So we discussed this for a while and she then arrived at the conclusion that he would have to keep on using condoms.

\section{-Yolanda Ruiz}

In addition to discussing the relationship between family planning methods and disease transmission, staff now talk about the ways in which various methods can potentially enhance sexual pleasure and relationships, depending on an individual's preferences. They emphasize that methods that provide a sense of security against both unwanted pregnancy and disease can help couples enjoy sex more because they will be less worried about possible adverse consequences.

\section{Rediscovering condoms}

Perhaps the most striking changes have occurred in the way in which providers themselves now approach condom use in their personal as well as professional lives. There is, within the family planning field, a historical bias against condoms. This stems from traditional views of the condom as a less effective method of family planning, although, when used consistently and correctly, condoms can be highly effective in pre- venting pregnancy. However, concern about their effectiveness with "typical use" (i.e., their being a user-dependent method), and the higher value given to longer-acting methods in terms of fertility reduction goals, prevented some providers from actively promoting their use.

At the beginning of the project, program directors at all three participating FPAs found that staff expressed resistance to condom promotion. While this response may in part have been a concern about effectiveness, they acknowledge that family planning professionals have a tendency to judge condoms differently in terms of their ability to prevent either pregnancy or HIV/STDs.

We place different values on each use of condoms [pregnancy prevention vs. HIV/ STD prevention] because we come from a family planning perspective. We are still looking at things from an unwanted pregnancy point of view. It is clear that we are judging and resisting changing our views because of our history of family planning provision. 


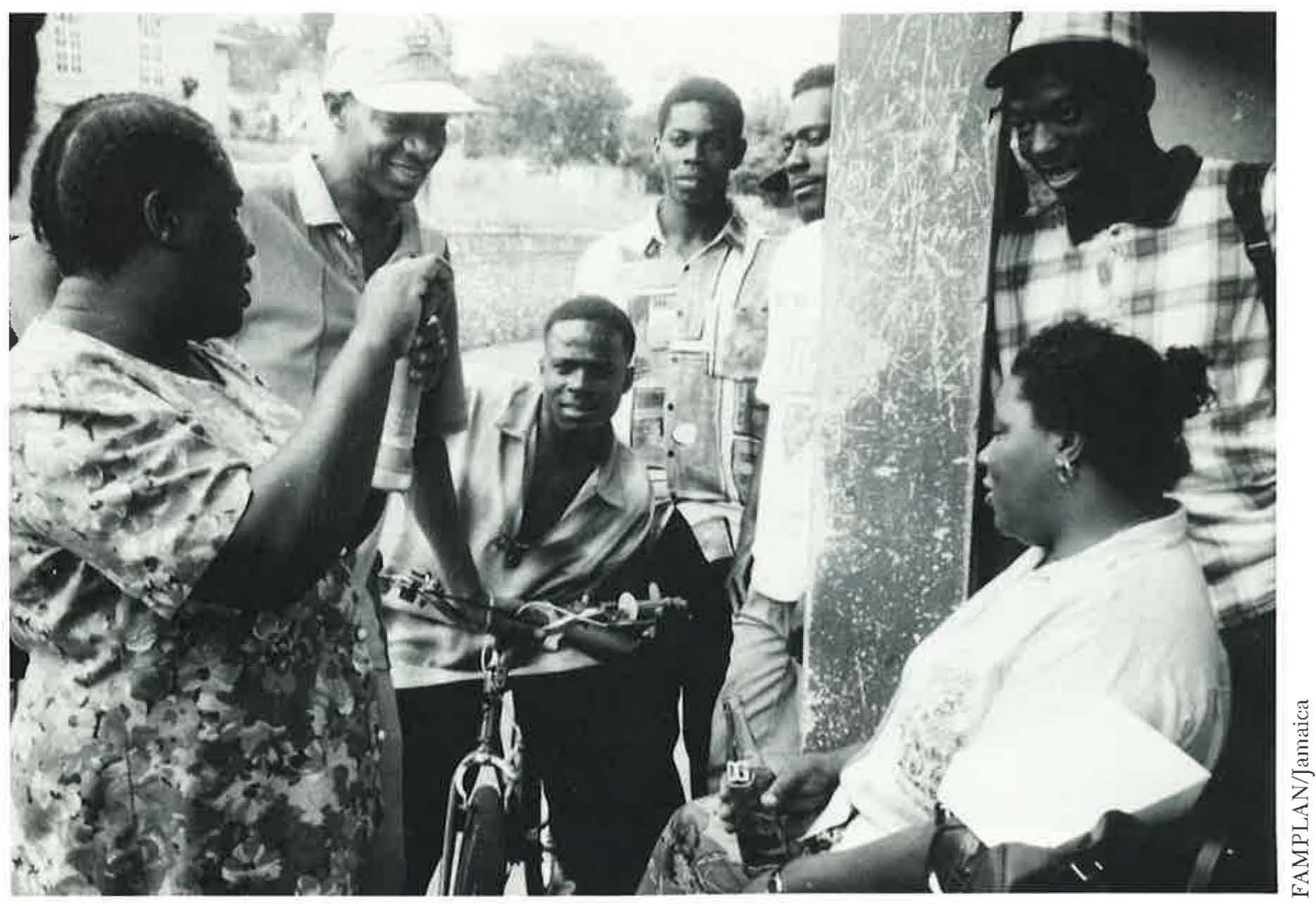

When trainers in both Jamaica and Honduras asked staff members how effective they thought condoms were, their responses were generally at or below the actual level of efficacy with typical use.

Before the new program began, staff promoted the condom mostly as a back-up method, or as a last choice when other methods were not feasible. Some would mention the condom's role in preventing STDs, but most had never opened a condom package to let a client touch it nor had they demonstrated how to use one correctly. One counselor at ASHONPLAFA/Honduras recalls: "Before we would talk about them in a very superficial way without doing a demonstration... Before, the truth is that we saw them as only a means of preventing pregnancy...but not as effective as other methods."

Given this bias, how did staff attitudes about condoms change? The Medical Director of BEMFAM credits training with helping staff to overcome their negative feelings:

In the staff training, use, storage, lubricants, erotic aspects were all brought up. The trainer even mentioned prostitutes putting condoms on with their mouths! This has changed the way that staff talk about condoms. Before they said "here it is." Now they have clients put them on a model and explain how to store them. They explain that condoms can enhance sexual relations because women have the opportunity to know men's bodies better and that condoms can intensify sexual response. Now we see an increase in condom use. After sensitizing staff to condoms, they even began to request them for their oun use!

\section{-Dr. Ney Costa, BEMFAM/Brazil}

In fact, some providers who are condom users themselves report that their own first hand experience has made it easier for them to explain proper use to clients. For example, an outreach worker at FAMPLAN comments: "When you go out there to talk to people, they usually ask the question, 'are you using the condom?' Before you go and tell them you have to start to practice. You can't tell them 'yes' while you're not, so you have 
to be honest with yourself." Another outreach worker proudly tells the story of how her son asked her for a condom and a pamphlet on proper use so that he could bring it to school to share with his friends at break time.

As their attitudes towards condoms have changed, staff have developed innovative ways of promoting their use. The techniques that they use and the information that they provide varies greatly from what was once standard practice.

Before we used to distribute condoms without explanation. Now we encourage clients to touch the condoms to see how soft they are. We tell them that they too can participate by putting them on their husbands as part of a pleasurable sexual act. There was resistance before. Women used to pass condoms like a hot potato. Now they carry them in their handbags. Now staff believe in the use of condoms.

- María Elena de Perez, ASHONPLAFA/Honduras

One counselor at BEMFAM/Brazil actually collects condoms that have been used in demonstrations and puts them in a box. During a group intervention, she has the participants close their eyes as they pass the box of condoms from one to another. Each woman comments on what she feels in the box. Clients use descriptions like "moist," "soft," "nice smell," and "strong" all of which demonstrate positive connotations and help them to redefine their opinion of condoms.

According to a staff member at BEMFAM/ Brazil, "These days, we dedicate time to anecdotes and ideas about condoms. We work to try to destroy prejudices against condoms, eroticizing them and encouraging female participation in their use." Another BEMFAM/Brazil staff member commented, "We now try to counteract the myth that condom use detracts from sexual pleasure by encouraging new techniques for pleasurable condom use as a part of the sex act."

Even the simple addition of a condom demonstration using a wooden penis model has made a fundamental difference in how staff communicate with clients about condoms. First of all, the model has served as an effective attention-grabber and ice-breaker. According to one outreach worker at FAMPLAN/Jamaica, "As soon as you go out there and you take out the penis model, you get their attention...and if people are passing and see it, they come nearer to hear what is happening."

Jamaican outreach workers have also developed strategies for proving the condom's reliability. Some put condoms under the water tap to show that a condom can be completely filled with water and still not burst while others ask a volunteer to put a condom over his foot as a vivid way of demonstrating the condom's ability to stretch. Still others blow them up like balloons. These demonstrations have succeeded in making a serious topic fun and engaging. After experimenting with different approaches, staff share successful strategies with one another.

Over the past several years, there has also been increased interest in condoms on the part of FPA clients. When offered free samples, nearly all accept them and some return for additional supplies. Rural outreach workers in Jamaica marvel at how eager some men are to get condoms. As members of the same community they serve, the outreach workers have gained their neighbors' trust by making themselves available to clarify information or supply condoms even after official working hours. In fact, according to several of them, it is not uncommon for customers in desperate need of condoms to wake them up in the middle of the night: "At 3:00 in the morning, you hear them calling, 'Nurse!' Late in the night, you hear them knocking... They come and bawl for you and [say], 'sorry to wake you up but I don't have nothing and I have to get something [for protection]" One outreach worker noted that demand for her products increases during holidays: "Easter Monday night, I couldn't sleep in peace at all!"

\section{What's Sex Got to Do with It? A lot!}

In order to understand a client's particular situation or to provide specific information on condom use, staff have been compelled to address sexuality issues on a deeper level. Before the new program, as most family plamning staff had focused exclusively on the risk of unwanted pregnancy, they tended to concentrate on the biological aspects of sexual intercourse rather than the emotional aspects of sexuality. But the AIDS epidemic has forced a change in perspective.

The HIV/STD issue has helped us to deal with sexuality in a more active way. When we just offered family planning counseling, 
we related sexuality to that limited perspective. The outcome [of integrated counseling] has been to "sexualize" our work.

\section{-Rita Badiani}

Initially, many staff reported feeling uncomfortable discussing the range of sexual behaviors in which people engage. They feared asking clients about their sexual lives, considering it to be inappropriate or intrusive. One provider in Brazil recalled finding it very difficult to accept female homosexuality: "I had strong prejudices in this area and I worked on it... I think that while I still have not reached 100 percent recovery, I have reached about 90 percent when it comes to being able to deal with female homosexuality. That was my greatest difficulty." Other staff members found it difficult to accept teen sexuality. For example, the receptionist at FAMPLAN/Jamaica would send girls who arrived in school uniforms home to change because she did not think that it was appropriate to acknowledge that school girls might be sexually active.

Over time staff have become more accepting of the full range of sexual expression. At first, some were surprised by how eager clients were to talk about their concerns and reveal their feelings about highly sensitive topics. For example, outreach workers at FAMPLAN/Jamaica describe their initial astonishment at clients' openness in discussing so-called taboo subjects such as homosexuality, anal or oral sex, extramarital affairs by both men and women, impotence, premature ejaculation, sexual abuse, and domestic violence:

What you're very surprised about sometimes, is when they're telling you what is actually happening... There was this girl who came and told me that she's a lesbian. and she wanted to buy the dental dam [for protection against HIV transmission]. She was not afraid to tell me. And knowing that she was just seeing me for the first time.

\section{Homework}

For FPA staff, many of whom were raised in conservative cultures where an open discussion of sexuality was not encouraged, the new approach does take some getting used to. In all three countries, staff have requested additional training in sexuality as there are times when they still feel unable to address some of the serious concerns their clients raise. On the other hand, some even report that their increased level of comfort in discussing sexuality at work has filtered into their home life as well:

I was raised in an environment where there wasn't...much information about it [sexuality]... My daughter who is 10 is coming to me asking things that I didn't learn about until I came here to ASHONPLAFA! So now I approach it with such naturalness that I don't feel embarrassed or ashamed to talk about it... with any other person, not my co-workers, the clients, my family, my friends.

\section{-Gloria Flores, ASHONPLAFA/Honduras}

The end result of "sexualizing" the counseling session is that clients better understand how their own sexual behaviors may place them at risk of both unwanted pregnancy and HIV/ STD infection. Providers report that many women actually seem relieved to find an empathetic person in whom they can confide.

Many providers report a sense of pride in being able to help clients realize that their concems are in fact "normal" and that they are not alone in their worries.

\section{Sexual Decision Making}

In the past, providers generally began counseling sessions by giving a standardized lecture on family planning methods. Now, in most cases, they begin with an exploration of the individual's circumstances, including her sexual life. As the provider talks with the client about her current relationships and sexual history, together they explore her level of risk-a shift that is not always easy or comfortable for the provider.

But, despite the difficulty, providers take comfort in the fact that by addressing sexuality in a forthright manner they are ultimately helping a woman protect herself from disease as well as unwanted pregnancy. One counselor recounts a session with a client that began in a routine manner, and probably would have remained strictly clinical had she not asked the client about her reasons for requesting a pap smear.

When I asked her why she had come for the exam, whether it was a routine check-up or 


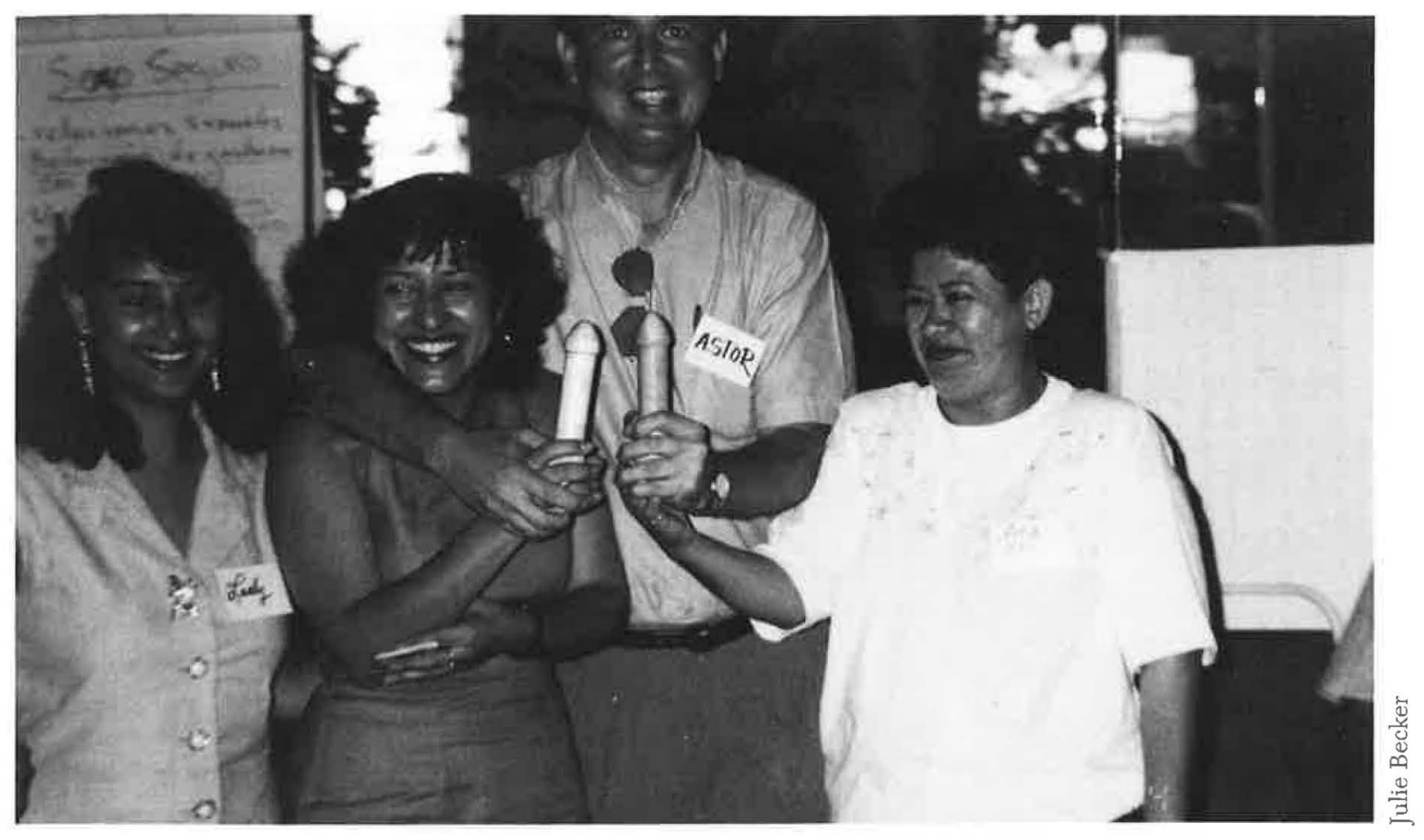

if she felt like she had a problem like vaginal secretion...she said, "look miss, I have a big problem that I've never told anyone about. But now that you've begun to ask me questions..." It turns out that she didn't come for the exam to find out if she had a problem but more than anything to find some sort of help... She revealed that she had been raped when she was 15 and that she got married at 18. After six years of marriage - she was now 24-she never knew what an orgasm was...she never felt sexual desire.

Through responding to my questions she felt like we had created an opening... I think that if I hadn't asked her these things, she probably wouldn't have had the opportunity [to talk] because they were about to send her to pay and then to see the doctor, and then that would have ended everything. We would have talked about the results of her exam, not what she really wanted to talk about. In the first place, explore, right? She didn't tell me right away that she had been raped. It was through exploration that the rape and all that came out.

—Gloria Flores

In one counseling session at FAMPLAN/Jamaica, by asking very direct questions about how the client would feel if she knew that her partner had other partners, the nurse learned that the client in fact knew that her boyfriend had another partner, his wife! She was the "other woman." Through discussion, the client revealed a very low level of self-esteem, and as the "other woman," she felt that she was in a powerless position to demand condom use. In this case, the exploratory process was critical to the counselor in understanding not only the client's feelings, but her needs as well.

Many clients face considerable barrierssocial, cultural, economic, gender-based--to condom use. Due to economic and emotional dependence on men, many women lack the power to insist that their partners use condoms. A program coordinator from FAMPLAN/Jamaica explained that: "Many of our clients are women of low socioeconomic status. They lack power. Men will beat them for sex. Men will beat women if they want them to wear condoms." She emphasized that within the Jamaican context, condom use becomes critical in light of the fact that it is common for both men and women to have additional partners outside of a primary relationship, and often these relationships are known to their partners.

A counselor at ASHONPLAFA/Honduras describes how difficult it can be to break through ingrained gender roles in Honduras that limit 


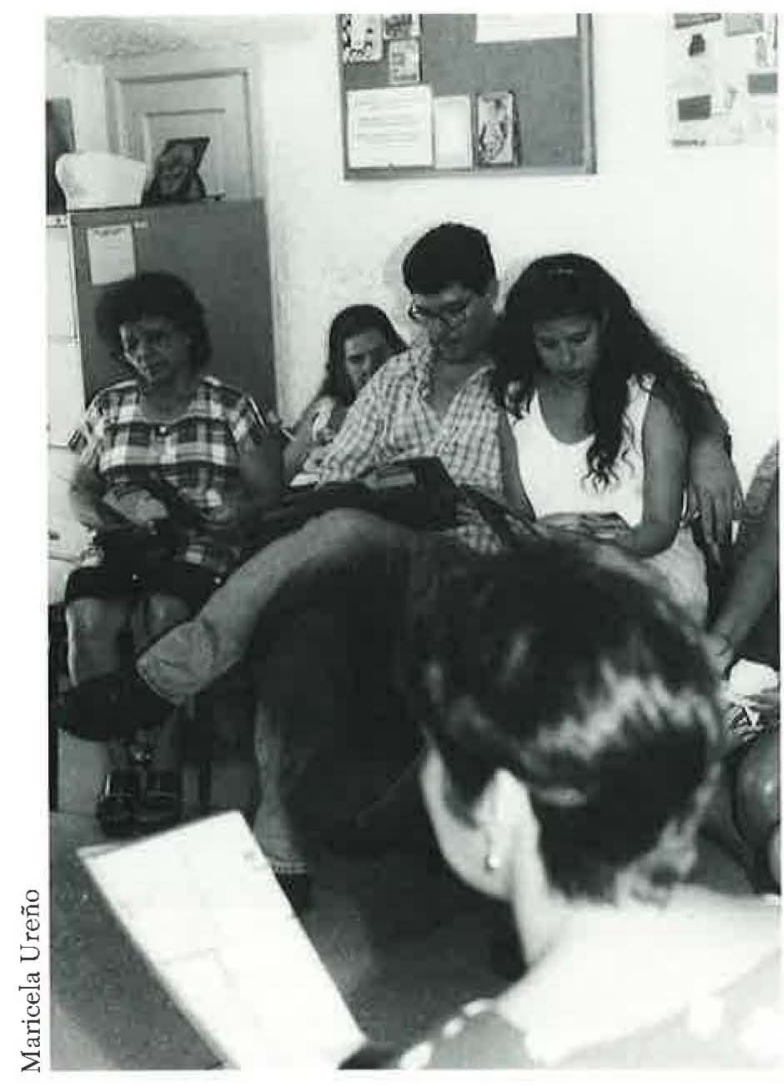

women's ability to negotiate method use with their partners:

More than anything for our clients here, it is difficult [for them to use methods] because of gender issues... Generally it is the man who makes decisions, he decides everything and it is difficult because our men think, for example, that using condoms has to be with prostitutes or women on the street... It's difficult when we talk with a woman and because she has a partner she doesn't even want to take a condom because she's thinking all the time, "but what will my husband say?..." The Honduran woman is extremely oppressed, violated sometimes because she is not even able to negotiate any aspect of her home, much less her sexual life, her sexual intercourse, or her life itself... It is difficult for her to negotiate with men because she is afraid that he is going to withhold from her or leave or reject her.

\section{- Yolanda Ruiz}

In many instances, a first consideration for a client may be to decide how she feels about the possibility of a future pregnancy, while weighing this against her perceived risk of disease. In a situation where abortion is unacceptable, inaccessible, or unsafe, the woman may need to assess her ability to ensure that condoms are used correctly and on a consistent basis. The counselor may explore the nature of the relationship the woman has with her partner, considering both her financial and emotional level of dependence.

If the woman fears that her partner will refuse to use condoms, the counselor can help her determine if she feels she might be able to convince him to do so. Besides his potential refusal, she may also fear that violence or sexual abuse could result from her request. Providers must understand that the woman may also risk losing her partner altogether, which could be emotionally or economically devastating.

In addition, the client may have biases of her own against condom use both in terms of efficacy and acceptability. She may perceive them as inhibiting sexual pleasure or view them as associated with prostitution or immorality. Finally, certain economic or logistical considerations may influence a woman's decision. For example, when confronted with the decision to use two methods or one, a client may make a decision based on her financial situation, her inability or unwillingness to purchase more than one method.

The following example of an actual counseling interaction underscores the importance of assessing the underlying factors that influence a client's contraceptive decision and her ability to protect herself from disease.

At ASHONPLAFA/Honduras, as soon as the client sat down with a counselor, she requested an IUD. However, after a few minutes of asking questions, the counselor discovered that the client was also concerned about contracting STDs from her husband, who frequently traveled. In response to the counselor's questions, she described an infection that had been treated earlier that year.

When the counselor asked if she had ever used condoms, she explained that she felt as if she could not ask her husband to use them, unless there was a medical reason that prevented her from using any other family planning method. She said that, otherwise, to ask her husband to use condoms, would imply a lack of trust on her part, and he would refuse to use them. Also, as a mother of eight children, she hesitated to use con- 
doms alone, fearing the risk of another pregnancy. Therefore, protecting herself against pregnancy was her highest priority.

Together with the counselor she decided to have the IUD inserted, but to tell her husband that she had been denied the IUD for medical reasons so that he would have to use condoms. In this way, she would be using two methods to meet her needs for both pregnancy and disease prevention, but without jeopardizing her relationship with her husband.

An important questions here is, of course, that by encouraging a client to adopt this solution, is the counselor failing to promote improved communication between the client and her partner? While open communication between partners is a laudable goal, providers must weigh the possibility of moving in this highly desirable direction against a client's possible need to protect herself at all costs. FPA staff must deal with dilemmas like this on a daily basis. In this case, the counselor recognized that while many men in Latin America support the concept of pregnancy prevention, at the same time they feel threatened, accused, or betrayed by a request to address the need for disease prevention. Men may perceive a woman's demand for condom use as evidence that she is questioning his fidelity or perhaps is being unfaithful herself - a double standard common in cultures where male promiscuity is common and women are more likely to be the monogamous partner.

A staff member at BEMFAM/Brazil told the story of one client who attended the FPA's women's discussion group three times. At the first session, the woman appeared anxious but remained silent. During the second session, she asked some specific questions about AIDS-related symptoms in an emotional manner. After the session, she requested individual counseling and during her meeting with the counselor she revealed that she was afraid that she might have AIDS. She described suffering symptoms such as night sweats, diarrhea, and weight loss since her husband's recent confession of infidelity and requested an HIV test.

Upon her return to the clinic fifteen days later, she appeared greatly relieved to find out that her test results were negative. Despite the scare she had experienced, at the third and final session, she admitted that she had not yet managed to confront her partner about condom use: "I know it's necessary, but I'm not brave enough to ask him to use a condom. He's my husband and if he admitted infidelity, at least he's honest." After discussing issues of self-esteem with the client once more, the staff member reported feeling utterly hopeless in the face of the woman's ingrained values, commenting: "Female passiveness is something so internalized that it is greater than the fear of death."

\section{Group Dynamics}

As there are clearly limits to what can be accomplished in one individual session, BEMFAM/Brazil has found that small group sessions, like those described above, are effective settings for fostering communication and negotiation skills. Known as the "Women's Project," these small group discussions for women (in some cases men attend as well) provide a safe environment in which women can express their concerns, give support to each other, and learn new communication skills. BEMFAM views them as a successful complement to individual counseling, and, based on the Brazilian model, the FPAs in Honduras and Jamaica have begun developing their own group intervention programs in both the community and clinic settings.

Prior to receiving medical services, all women who attend BEMFAM/Brazil clinics in several locations are invited to participate in a small group discussion led by a specially trained facilitator. Together, they read and discuss comic book-style booklets that feature stories reflecting the realities of women's lives and exploring issues related to HIV/STDs, risk perception, and partner communication. The booklets are used to lead into broader discussions about health, sexuality, and relationships.

The sharing of life stories allows women to recognize that they are not alone in their feelings. The group setting permits women to express themselves and practice more assertive behavior in a nonthreatening environment, helping them to overcome feelings of intimidation in communicating with their partners about sexuality and preventive practices.

\section{—Rita Badiani}

An example of the positive changes observed in clients as a result of participation in group sessions is a woman who attended two sessions where 


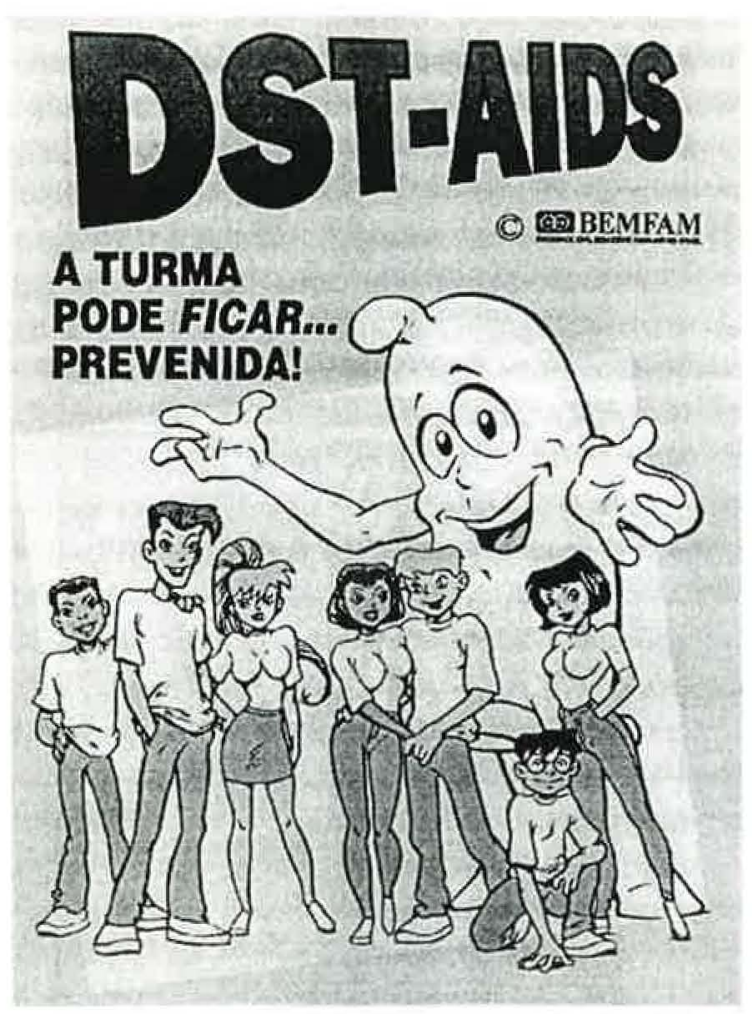

she expressed her desire to become less dependent on her partner by seeking employment. She came back the third time proudly reporting to the group that she had found a job. Another woman who, after participating in the group three times, had successfully persuaded her husband to use condoms told the group:

Afterfighting many times, I got my husband to use a condom. I screamed and wailed. I told him that his penis was thicker and more pleasurable [with a condom]. He has been using condoms now for three months. Now I feel more secure and indeed feel pleasure.

In addition to helping clients to articulate their concerns, both informal and formal group work are often an effective way for clients' true needs and interests to emerge. For example, during a waiting room discussion in Jamaica about HIV, STDs, and family planning, conversation quickly turned to clients' deep concerns about sexual abuse in their community. Although these women were very concerned about the risk of HIV transmission, it was clearly sexual abuse (and the broader risks entailed, including HIV transmission) that they felt needed to be addressed.

\section{INSTITUTIONAL IMPLICATIONS}

Launching a new, innovative program such as this has required more than simply training staff to adopt new techniques. It has required that the FPAs make changes at the institutional level, challenging existing management structures and staffing patterns.

\section{Commitment}

Project Coordinators at all three FPAs have emphasized that in order to achieve success, it is essential to secure the FPA's commitment to the new program and acceptance of its place within the FPA's overall mission. According to Rita Badiani from BEMFAM/Brazil, if an FPA's mission is to "provide high-quality sexual and reproductive health services," then all programs and services-including those related to HIV/STD prevention and treatment-must contribute to attainment of this larger objective. In other words, an imnovation's underlying philosophy must become imbedded within the overall goals of the institution. Along these lines, FAMPLAN/Jamaica's executive director comments:

Change has to be well-managed given the resistance at any attempt to change old methods and concepts. Top management commitment to the program must be very real and apparent from the beginning, and this commitment must be sold to all staff, especially those implementing the project. Staff should be involved in every stage of this process, program planning, implementation, and evaluation.

\section{-Peggy Scott}

\section{Structural Issues}

The FPAs have discovered that the placement of these projects within the organizational structure of the FPA can influence the way in which the new approach takes root within the institution. For example, at ASHONPLAFA/ Honduras, it was found that when the program was initially placed under the jurisdiction of a new staff member hired expressly for that purpose, other staff members perceived the program as a separate and isolated effort. As a program manager explains: 
When they named a new coordinator for a project on education and counseling, there was staff resistance because there was a new person receiving a salary. The thought was: "This new person is responsible. I have my own work already defined. Now that person will do work in that [HIV/STD prevention] area." It is hard to motivate people and to make them understand that the project belonged to the whole FPA and not to one person or one department. It was a difficult process. It took time... But people eventually came around... Now I am convinced that the staff have identified with the project as part of the institution.

\section{-Maria Roberta Bulnes}

In fact, the main reason the new program managed to flourish in Honduras was because of the intense involvement of junior staff who organized themselves as a result of their shared personal commitment to HIV/AIDS prevention and treatment. These staff, in turn, have been the catalyst for management ultimately becoming committed to the new approach. On the other hand, from the beginning BEMFAM/Brazil placed the new initiative directly in the hands of existing high level managers, so the program was readily implemented and accepted by all staff.
Despite these administrative differences, program managers at all three FPAs have found that the new program has occasionally challenged established lines of authority. As much of the work is interdisciplinary and crosses departments, confusion over supervision has occurred when program oversight or coordination rests with one department while staff from many departments within the organization are responsible for implementation.

\section{ACCOMPLISHMENTS TO DATE}

\section{Changes Observed}

As described above, dramatic changes in the manner in which services are provided have been observed in all three FPAs in a relatively short period of time-the three to four years since the initiative began. While some positive changes were apparent after initial trainings of only two or three days, it has taken longer for staff to refine skills, develop comfort with these issues, and learn how to integrate the changes within the constraints of the clinic setting. Many counselors, for example, first shifted from a focus on providing information about contraceptives, to a focus on giving information and advice about HIV/AIDS. They then moved on to elicit information about

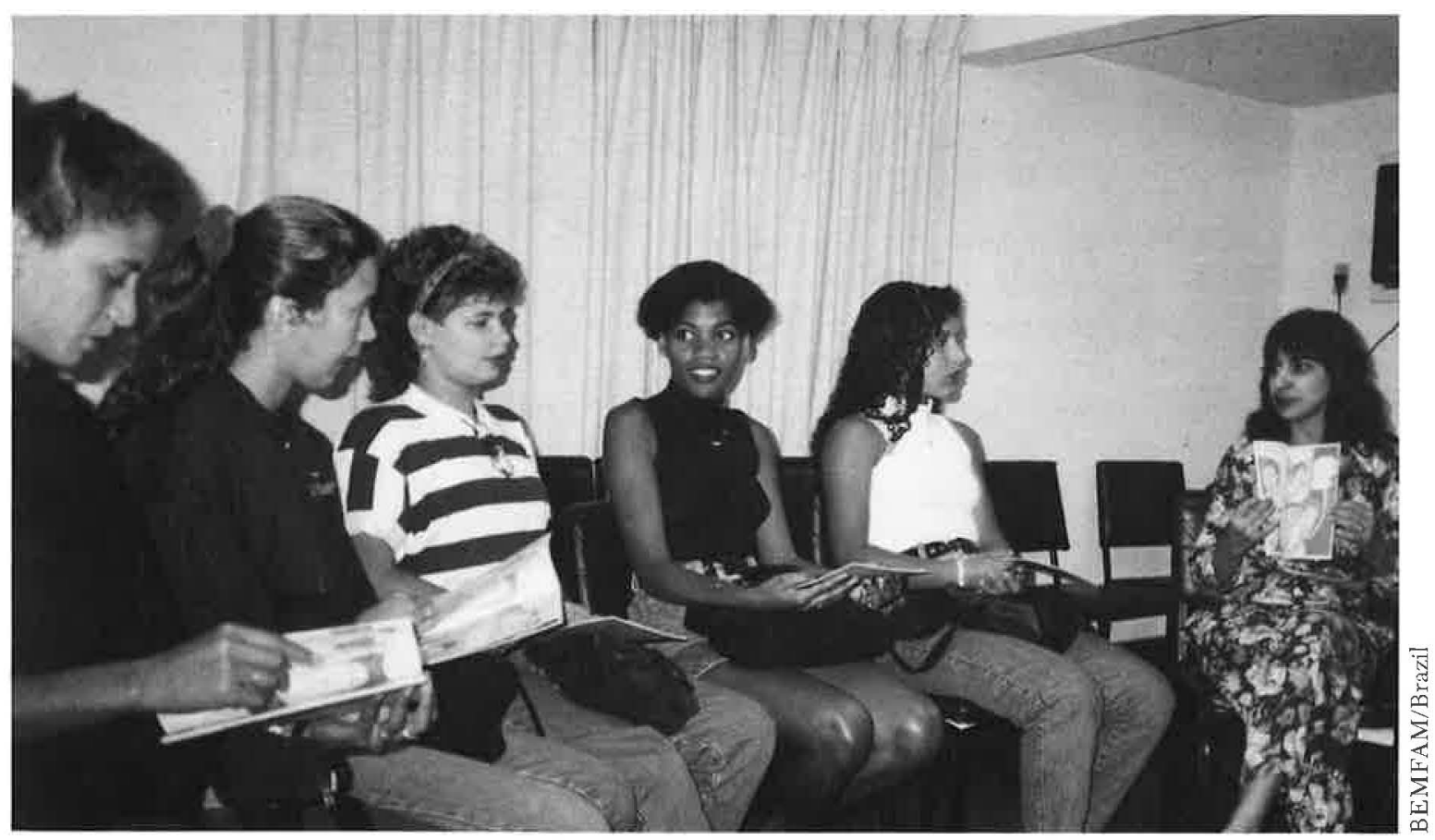


risk and then, over time and with ongoing feedback, they became comfortable using a two-way process to explore the client's situation. Institutionalization of the new approach has also been a long-term process, involving a permanent change in the manner in which family planning services are provided. Staff have received ongoing training, feedback, and support from colleagues, superiors, and IPPF/WHR throughout the course of the project. A mechanism must be planned to assure refresher training and ongoing support once funding is withdrawn.

\section{Improvements in the Quality of Family Planning Services}

By far the most noticeable change has been increased condom use. Although overall condom distribution increased dramatically in the first year of the project, many other factors related to condom availability and access limited the numbers distributed in subsequent years. Still, staff report that clients are increasingly requesting condoms. In Jamaica and Honduras, free samples are given to all new clients and counselors report that over 90 percent accept them. Some clients indicate that they are putting them in their partners' suitcases or drawers, or giving them to their adolescent children. In Brazil, 36 percent of clients adopting family planning for the first time now select condoms, and 5 percent elect to use dual methods. Women who participate in group discussions receive samples of condoms and many return for additional supplies.

\section{Effects on Staff's Personal Lives}

Some staff have indicated that their experience with the program has assisted them in their personal lives, particularly in terms of communication within their own families. As one staff member in Brazil reports: "I find that I have become a better person, not just a better BEMFAM employee. Even my conversation at home has improved in some cases." Program managers in both Brazil and Honduras have also reported that staff are increasingly requesting condoms for their own use.

A physician from BEMFAM/Brazil describes how he has been able to relate his work to his personal life:

The training certainly served not only for my professional life, but for my personal life as well, as a person loving, living, suffering, enjoying. The truth is, working is like a classroom in human relations. You relate what you learn [from working with clients] to your relationship with your father, your mother, your wife, your child, whomever you are relating to...you can extrapolate what you learn because the patient is a human being.

-Dr. Roberto Dias Fontes

\section{BARRIERS TO CHANGE}

The changes in staff practice called for under this program have not always been easy to institute, and each staff member has approached the program with a different level of interest and openness.

\section{Staff Resistance}

Some staff members, particularly those who had carried out their work in a certain way over many years, expressed an initial reluctance to alter their approach and responsibilities and demonstrated a certain level of resistance to change. Peggy Scott of FAMPLAN/Jamaica stresses that: "Change in the work environment inevitably causes some amount of tension, and this was as expected." Some staff felt hesitant to deal with issues that directly addressed sexuality. For example, at BEMFAM/Brazil some female physicians were initially resistant to the idea of performing STD examinations on male clients. The medical director of the BEMFAM/Brazil characterized their hesitation:

Their husbands did not like the idea of them taking care of men and touching their penises... Now women doctors are performing [examinations] without a problem. Only one woman has refused because of pressure from her husband.

$$
\text { -Dr. Ney Costa }
$$

\section{More Work?}

At the beginning, some staff at all three FPAs were concerned that the new program would mean extra work without additional compensation. According to Joan Black of FAMPLAN/Jamaica, this initial perception was a diffi- 
cult barrier to overcome: "The staff had mixed feelings... Some said that they needed more money because they worked more...they believed that it took more out of them, so they should be compensated." Once staff understood that rather than taking on additional tasks, they were being asked to change the way in which they carried out the tasks they already performed, feelings about increased compensation subsided. In Jamaica, job descriptions were simply revised at the time regular salary increases were being given.

\section{Not Enough Time?}

With many clients to see daily, staff often feel pressed for time and are acutely aware of the number of clients in the waiting area. Initially, some staff feared that the new approach would take additional time and lead to a backlog of clients. Over time, however, they have found that with practice, the new approach does not necessarily entail longer sessions with clients. By starting counseling with a focus on the particular circumstances of the client, counselors are better able to tailor the counseling session to meet their needs, eliminating extraneous information that they previously would have included. They have found that, in reality, time can often be saved by centering the session around the par- ticular needs of each client. In Brazil, increased emphasis on group interventions in the clinics has proved to be an effective and efficient use of staff time.

\section{FACTORS THAT HAVE FACILITATED CHANGE}

While training has been instrumental in facilitating attitude and practice change among FPA staff, other factors have also contributed. Throughout the gradual process of reconceptualizing and redefining job descriptions based on the new approach, staff have identified several specific agents of change.

\section{The Changing Nature of the AIDS Epidemic}

As more and more people become directly or indirectly affected by HIV/AIDS, staff have changed their perceptions about who is at risk. As they now view the situation as being "closer to home" (i.e., that family planning clients are also at risk), their attitudes have changed. They now recognize the importance of addressing these issues within their professional practice.

At the beginning, HIV/AIDS was perceived as a homosexual disease, progressing to a

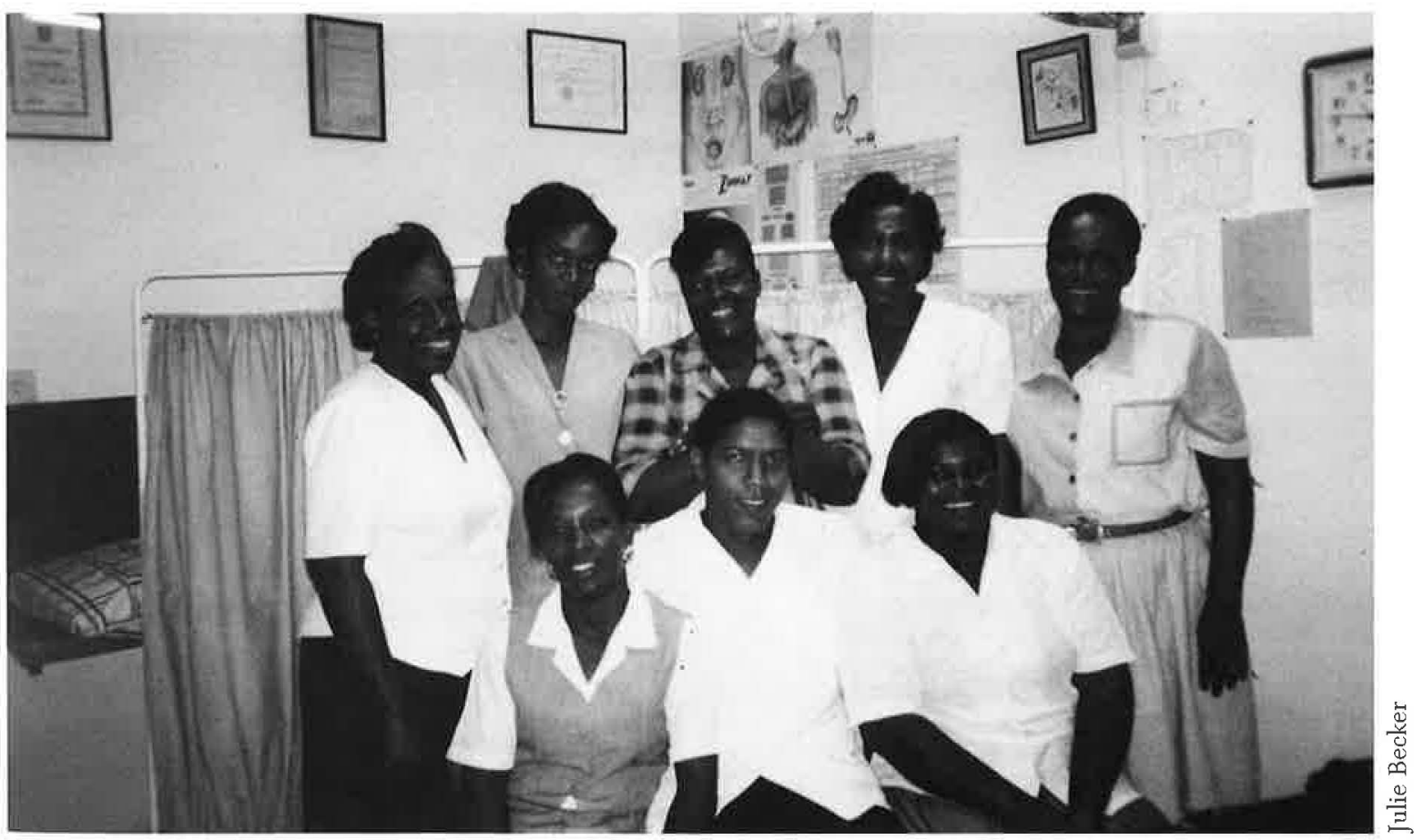


disease among the sexually promiscuous or prostitutes. It was believed that heterosexuals were in no danger especially if they were married or in a steady relationship. The FPA, realizing the increasing numbers of persons succumbing to the disease, was influenced to help counteract the spread of the disease.

$$
\text { -Peggy Scott }
$$

\section{A Sense of Personal Commitment}

In many ways, AIDS itself, as a concrete threat against which people can organize, has served as a motivating factor for FPA staff. AIDS has provided the catalyst for developing a true understanding of the usefulness of working within a framework of broader sexuality and sexual health. AIDS has provoked deep concern among staff, prompting them to assume responsibility for protecting their clients and their communities from disease. As a promotion supervisor from ASHONPLAFA/Honduras, explains: "My perspective has changed. Seeing people fighting for their lives, I now feel a moral obligation to teach others how to protect themselves." And a counselor from ASHONPLAFA/Honduras reflects:

What has motivated me is that it is a very beautiful social work. That it is a life that we are going to save. This is something that I am doing for myself and for my loved ones, especially my daughter.

—Thesla Bustillo

Many ASHONPLAFA/Honduras staff members mention that they know someone who is currently infected with HIV or who has died of AIDS.

\section{Peer Influence}

Staff members at all three FPAs have attributed, in part, the successful adoption of the new approach to a sense of solidarity among their colleagues. As staff have witnessed changes in their peers' attitudes and practices, they have been influenced to adopt a more integrated approach themselves. For example, ASHONPLAFA/ Honduras's Equipos Motores (motivation teams) work with FPA staff within each district. Contests organized by these teams have resulted in the creation of murals, educational materials, poetry, and short stories on themes of sexual health, thus creating a sense of healthy competition between the various centers. According to a member of the Equipos Motores, "As we acquire experience and modify the way in which we approach problems and address new issues, peer influence has been

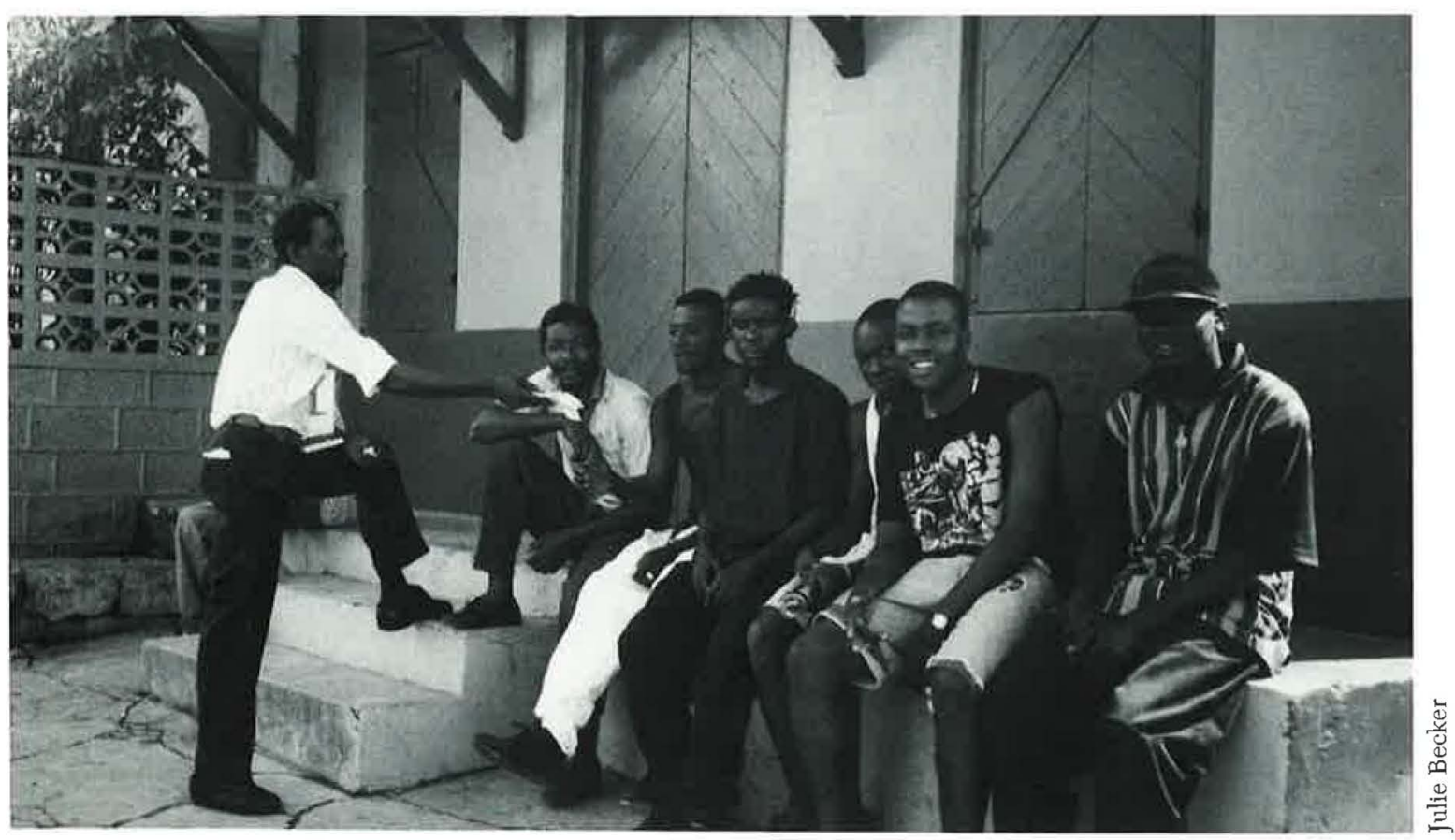


an important source of change." Another adds: "We spur each other on by always giving each other support and by sharing experiences, more than anything."

Similarly, a discussion with rural outreach workers from FAMPLAN/Jamaica demonstrated that there, too, staff members have relied upon each other for support; they identified coworkers as important sources of both encouragement and new ideas on how to interact with clients.

\section{Providing New Professional Challenges}

The demands of the new program have also provided staff with new professional challenges. Assuming new responsibilities has motivated many to augment their professional development. Many staff express a real sense of personal satisfaction with their new roles. "Well, for me this [project] has been a great help. You're now seeing the fruits, and this is satisfying, as an employee, as a counselor, and as a person."

ASHONPLAFA/Honduras and FAMPLAN/ Jamaica have found that by involving support staff in education and counseling activities they have provided them with a greater sense of recognition and participation that has boosted morale and enhanced client interactions. For example, at FAMPLAN/Jamaica receptionists and drivers have expressed enthusiasm over the informal discussions that they now facilitate with clients in the waiting room. At ASHONPLAFA/Honduras, a wide variety of staff, including the cytologist, drivers, and administrative staff, have become more involved in counseling and educational activities: when the cytologist is not busy with pap smears, she now comes out of the lab to initiate informal discussions with clients in the waiting room; the drivers have formed their own organization, initiating conversations with clients in waiting rooms and communities; and administrative staff have participated in special public awareness events, including health fairs and World AIDS Day activities.

\section{Lessons Learned}

1. The importance of institutional commitment to the sexuality concerns of clients cannot be overemphasized. By placing responsibility for inclusion of the discussion of sexuality directly under top managers, who carry sig- nificant responsibility, such a controversial innovation can secure institutional commitment. Unless there is commitment at the top levels, including a willingness to devote the time and resources required, an innovation of this magnitude could never be accomplished. Likewise, management must also provide a supportive environment in which people can honestly explore their own attitudes on such an intimate subject and then support and encourage them as they begin to implement the often difficult transition into how they interact with their clients on a daily basis.

2. Involving all staff in planning, implementation, and monitoring of the introduction of sexuality discussions with clients gives them a sense of personal ownership. Even staff who do not traditionally take responsibility for direct client education greatly enjoy this added dimension to their work-it makes them feel more involved and that they are helping to forward the goals of the organization. For example, in Honduras everyone from the cytologist to the drivers is involved in some aspect of counseling and education; in Jamaica receptionists and drivers express great satisfaction with the informal discussions they now carry on with clients in the waiting room.

3. While training is essential, it alone is not sufficient to change attitudes about clients' sexuality or the willingness to discuss intimate matters with clients. As Dr. Fathalla so clearly noted in his Introduction, "it is easier by far to impart new knowledge to service providers or help them to acquire new technical skills" than is "actually changing their attitudes, particularly when the issue is a subject such as sexuality." Attitude change is rarely instantaneous; rather, it is an ongoing process. Providers need the support of their supervisors as well as the opportunity to share experiences with their colleagues on a regular basis.

4. Including a discussion of sexuality as part of the counseling process, rather than taking up precious time, actually saves time. Because this approach allows individual clients to come forward with their most immediate needs, providers are able to zero in rather rapidly on what information or behaviors the clients need explained. This saves time over the previous approach in which providers would recite the full range of methods and services available irrespective of clients' specific needs. 
5. Individualized counseling and service delivery improves the quality of service offered to each client and, at the same time, gives providers a greater sense of accomplishment. The staff participating in these three programs report a greater level of satisfaction with their work since the discussion of sexuality was included. They feel they are now making a difference in people's lives. Many also report that the positive changes have carried over into their personal lives as well, making them more aware and caring people.

6. Contrary to expectations, there is very little difficulty getting clients to discuss their sexual lives openly. In fact, many women and men seem relieved to finally have someone to talk to, to know they are not alone in facing problems such as potential infection, lack of sexual fulfillment, partners' infidelity, and the like. This positive response has been a prime motivator for staff to continue perfecting this new approach to client interaction.

7. As a corollary to the willingness of individuals to discuss their sexuality concerns, it was found that group discussions of sexuality were also highly acceptable-especially to women. Many women found the groups empowering insofar as they could discuss issues of human sexuality, gender inequity, and power relationships with their peers in a forum where a trained facilitator was available to lead the discussion, answer questions, and provide information about sources of support and direction available in their community. At several BEMFAM/ Brazil locations, all women who come to the clinic are invited to join a discussion group. Staff report that the group setting not only allows them to express themselves in a safe environment but also provides a forum for them to practice techniques for being more assertive and communicating more openly with their partners.
8. Adoption of a sexuality-based ap- proach has resulted in a significant increase in condom use. Prior to this project, condoms were rarely promoted as a method and were usu- ally recommended only as a backup to other con- traceptives in all three FPAs. Today they are in the forefront, with increased use by both clients and staff. Where before many staff would not have

been able to demonstrate correct condom use, today they are eager to show clients on a penis model. So clients no longer leave with just a sealed packet in their hands, but knowing how to put condoms on, how to dispose of used condoms, how effective condoms are for pregnancy prevention as well as protection from STDs, and tactics to negotiate condom use with a potentially reluctant partner. Several clinics also report a growing number of clients who have decided on dual method use (condom plus another contraceptive) in response to own assessment of their needs in their particular situation. And lastly, the number of condom users among FPA staff has also increased.

In sum, through this project FPA managers and staff feel that they are changing the way they provide services for the better by increasing emphasis on clients' needs and the circumstances of their sexual lives, which has greatly improved the quality of their work.

\section{Notes}

1. The World Bank. 1993. World Development Report: Investing in Health. New York: Oxford University Press.

2. The funcling was provicled through an add-on from the USAID Office of Health to the USAID Office of Population-funded Transition Project.

3. Quotes originally in Spanish were translated into English for writing of this booklet. The process of translating the entire article into Spanish may change the wording of some quotes.

\section{Acknowledgements}

We would like to extend our thanks to the entire staff from BEMFAM/Brazil, ASHONPLAFA/Honduras, and FAMPLAN/Jamaica, and particularly to those who participated in the discussions, in-depth interviews, and focus groups that assisted in preparing this publication.

BEMFAM: Rita Badiani and Ney Costa, Project Coordinators.

Maria José Sabino, Angela Maria Dantas, Jane Nunes, Maria de Fátima Oliveira, Gilson Oliveira, Edilma Costa, Francisca Moura, Luciene Octacilio, Virginia Andrade. The focus group was conducted by Katia Moura, Maria do Socorro Silva, Catarina M. Da Silva, Vania Bastos Petti, Cleusa Souza dos Santos, Elizabeth Afonso, Maria Luiza da Silva, Roberto Dias Fontes, Dilmara da Cruz Andrade, Jussara Rocha, Gilda Maria Dutra, Lucia Maria Costa, Josenilda de Carvalho, Katia Mora, Interviews were conducted by Maria Regina Oliveira and Sonia Dantas.

ASHONPLAFA: María Elena de Perez, María Roberta Bulnes, Project Coordinators. Gloria Flores, Thesla Bustillo, Yolanda Ruiz. Interviews conducted by Julie Becker:

FAMPLAN: Dunneth Willocks, Una Watson, Larnes Small, Beverly Ringrose, Melrose Jones, Carmen McKenzie, Lilieth Richards, Marcia Broderick, Beverly Lambert, Yvonne Woodbine, Pauline Pennant. The focus group was conducted by Maricela Ureño, Richard Reid, and Joan Black.

We would like to acknowledge the following people who provided invaluable assistance in preparing this publication: Maricela Ureño, Claudia Mora, Judith Helzner, Ann Denise Brown, Elizabeth Kirberger, Doris Bertzeletos, and Nicholas Frost. 


\section{Resumen en Español}

Esta edición de QUALITY/CALIDAD/ QUALITÉ relata la experiencia de tres asociaciones de planificación familiar (APFs) afiliadas con la International Planned Parenthood Federation/Western Hemisphere Region (IPPF/WHR) que han tratado de incorporar una estrategia de prevención del VIH/SIDA en su esquema de trabajo cotidiano. Se examina cómo BEMFAM/Brasil, ASHONPLAFA/Honduras y FAMPLAN/Jamaica han logrado una transición hacia una oferta de servicios de planificación familiar más enfocada en los clientes mismos y más explícita en el tratamiento de temas sexuales.

En 1992, cuando este proyecto tomó marcha con el apoyo de la U.S. Agency for International Development (USAID), existía muy poca experiencia sobre la integración de la prevención del VIH/ SIDA con la planificación familiar. Cada APF debía elaborar una estrategia particular en base a sus propias estructuras de servicio, sus propias percepciones de las necesidades de los clientes, y los intereses y conceptos particulares del personal. Al iniciarse el proyecto eran pocos los trabajadores en planificación familiar que conocían de cerca al VIH/ SIDA. Con la aparición de la enfermedad, los trabajadores en las APFs descubieron la importancia de motivar a sus clientes a que adoptaran comportamientos sexuales menos riesgosos. Pero también vieron que no lo podrían hacer sin atender primero a los factores subyacentes que influyen en la capacidad de decisión y control sexual de cada cliente.

En cada uno de los tres países, el personal de las APFs recibió capacitación especial que no sólo los habilitó para proveer información sobre el VIH/ SIDA, sino que también les ayudó a adoptar un concepto más amplio de la sexualidad y la salud reproductiva en sí. Dicha capacitación también permitió que el personal indagara más a fondo en los aspectos de la sexualidad, aprendiendo nuevas maneras de manejar estos delicados temas con sus clientes. La capacitación también trató temas de género y poder y proporcionó técnicas para ayudar al cliente a comunicarse y negociar con su pareja. Aunque hubo variaciones entre las tres APFs, cada programa de capacitación trató los siguentes temas: comodidad con el vocabulario sexual; clarificación de valores; desarrollo sexual; definiciones de salud sexual y reproductiva; vida sexual y percepciones de riesgo del cliente; género, poder y relaciones sexuales; sexo sin riesgos; planificación familiar desde una perspectiva sexual y de salud reproductiva; y enfermedades de transmisión sexual.

Entre las lecciones aprendidadas por las APFs en Brasil, Honduras y Jamaica se destacan: 1) la importancia de un compromiso institucional en el que la gerencia provee un ambiente que facilita la exploración honesta de actitudes sobre temas íntimos, apoyando a la vez el cambio paulatino de estas actitudes y de modalidades de atención del personal a los clientes. 2) La importancia de incluir a todos los niveles del personal en la planificación, implementación y seguimiento del nuevo programa, dado que todos-desde el citologista hasta el chofer-aprecian la oportunidad de participar en algún aspecto del asesoramiento y la educación. 3) La capacitación, aunque es fundamental, no es suficiente como para cambiar las actitudes del personal sobre la sexualidad de los clientes, o para hacer que los proveedores estén más dispuestos a discutir cuestiones íntimas con los clientes. La evolución de las actitudes del personal ocurre de manera gradual y contínua, y sólo cuando los supervisores apoyan el cambio y proporcionan frecuentes oportunidades para que los proveedores compartan experiencias al respecto entre sí. 4) Aunque muchos suponen que discutir la sexualidad con el cliente consume demasiado tiempo, en realidad estas conversaciones suelen ahorrarle tiempo al asesor. Esto ocurre porque la discusión abre puertas y permite que el cliente exponga sus necesidades más urgentes, lo cual ayuda a que el proveedor identifique de inmediato la información o el comportamiento que el cliente necesita comprender. 5) Al contrario de lo que se suele suponer, no es difícil lograr que los clientes hablen sobre sus vidas sexuales con franqueza. Es más, muchos hombres y muchas mujeres se muestran aliviados cuando por fín pueden conversar con alguien sobre estos temas. Resulta alentador descubrir que uno no es el único que enfrenta problemas como la posibilidad de quedar infectado, la falta de satisfacción sexual, o la infidelidad conyugal. 6) También se descubrió que la discusión de temas sexuales en grupo resultó muy aceptable-especialmente para mujeres. Muchas mujeres respondieron con entusiasmo a la oportunidad de hablar sobre sexualidad, desigualdades de género y las relaciones del poder en un foro dirigido por una facilitadora capaz de contestar preguntas y proveer información sobre fuentes de apoyo y dirección en sus propias comunidades. 7) La prestación de servicios de planificación familiar enfocada en la sexualidad también ha resultado en un importante aumento en el uso de condones entre los clientes. Antes de este proyecto, las tres APFs casi nunca promovían condones como métodos anticonceptivos, o sólo los recomendaban como "respaldo" para otros métodos. En la actualidad los condones son una de las principales opciones anticonceptivas ofrecidas por esas APFs, y el nivel de uso ha aumentado tanto entre los clientes como entre el personal. 


\section{Résumé en Français}

Cette édition décrit l'expérience de trois associations de planification familiale (APFs) affiliées à l'International Planned Parenthood/Western Hemisphere Region (IPPF/WHR), dans l'intégration de préoccupations sur le SIDA et le VIH dans leur travail. Elle explore comment, dans la prestation des services de planification familiale, le personnel de BEMFAM/Brésil, ASHONPLAFA/Honduras, et FAMPLAN/Jamaique a fait la transition vers une approche qui soit centrée davantage sur le client et sexuellement plus explicite.

En 1992, quand le projet a débuté avec le support de l'Agence des Etats Unis pour le développement international, on avait très peu d'expérience dans l'intégration de la prévention du SIDA dans le planning familial. Cela veut dire que chaque APF devait développer une approche unique basée sur la structure de ses propres services, les besoins apparents des clients, et, en particulier, les intérêts et les idées de sa direction et de son personnel. Quand le projet a commencé, quelques-uns seulement des membres du personnel connaissaient la maladie en profondeur. Mais, quand le VIH/SIDA est devenu plus proéminent, le personnel a été incapable d'aider les clients à avoir des relations sexuelles moins risquées sans aborder, au préalable, lẹs face teurs sous-jascents qui influencent la capacité des clients à contrôler leur vie sexuelle et à prendre de. bonnes décisions.

Dans les trois pays, en plus des informations sur le SIDA et le VIH, une formation adéquate a permis au personnel de mieux comprendre et définir le concept plus global de santé sexuelle et santé en matière de reproduction, d'explorer les questions reliées à la sexualité, et, d'acquérir de nouvelles aptitudes à communiquer avec les clients sur ces sujets délicats. Les sessions contenaient également des questions relatives an genre, aux disparités de pouvoir, et an développement de techniques pour aider les clients à communiquer et à négocier avec leur partenaire sexuel. Bien qu'il y avait des variations entre les trois APFs, les thèmes couverts par chaque programme englobaient: l'aisance avec le language sexuel, la clarification des valeurs, le développement sexuel, la définition de la santé sexuelle et de la santé en matière de reproduction, la vie sexuelle du client et les risques perçus, les inégalités entre les sexes le pouvoir et les relations sexuelles, les précautions à prendre au niveau sexuel la planification familiale du point de vue santé sexuelle/ santé de la reproduction, et les maladies sexuellement transmissibles.

Les leçons importantes apprises des expériences du Brésil, de l'Honduras et de la Jamaique couvrent les points suivants:
1) l'importance d'un engagement institutionel et la nécessité de la direction de créer un cadre de travail et environnement qui encourage le personnel à explorer leurs propres attitudes sur ces sujets intimes et à les encourager lorsqu'il commence à changer la nature de leurs interactions avec les clients; 2) l'importance d'inclure tout le personnel dans la planification, l'exécution, et le suivi du nouveau programme, ce qui lui donne un sens de responsabilité envers celui-ci: du cytologiste au chauffeur qui apprécient le fait de participer à tous les aspects du programme: que ce soit les consultations ou l'éducation; 3) la formation qui est essentielle mais pas suffisante pour changer les attitudes des clients envers la sexualité ou le désir des prestataires de discuter des affaires intimes avec leurs clients. Le changement d'attitude est un processus continue et les prestataires ont besoin du support de leur superviseur et de l'opportunité de partager leur expérience avec leurs collègues de manière régulière; 4) inclure une discussion de la sexualité dans le processus amenant aux consultations ne prend pas de temps, il permet plutôt d'en gagner: ceci est dû au fait qu'il donne à chaque client la possibilité de partager leurs besoins les plus immédiats et qu'il aide les prestataires à se focaliser sur les informations ou les comportements sur lesquels le client a besoin d'explications;

5) contrairement à ce que l'on croit, il n'est pas difficile d'amener les clients à parler de leur vie sexuelle d'une manière ouverte. En fait, de nombreux hommes et femmes semblent être soulagés de pouvoir parler à quelqu'un, de savoir qu'ils/elles ne sont pas seul(es) en face de problèmes tels qu' une infection, un manque de satisfaction sexuelle, ou l'infidélité du partenaire;

6) on a aussi trouvé que les discussions de groupe sur la sexualité étaient tout à fait acceptées - surtout par les femmes. De nombreuses femmes ont trouvé que les groupes les rassuraient dans le sens où elles pouvaient discuter de questions de sexualité, d'inégalité entre les sexes et des relations de pouvoir avec des collègues dans un environnement où un facilitateur habile est capable de diriger la discussion, de répondre à des questions, et de donner des informations sur les sources de support et de conseil disponibles dans la communauté; 7) l'adoption d'une approche basée sur la sexualité a également eu comme résultat une augmentation significative de l'utilisation du condom. Avant ce projet, les condoms étaient rarement promus comme méthode contraceptive et étaient généralement recommendés comme appui supplémentaire à d'autres contraceptifs dans les trois APFs. Aujourd'hui, ils sont mis en avant, avec une utilisation accrue de la part des clients et du personnel. 
Julie Becker currently manages the HIV/STD Prevention Program of the International Planned Parenthood Federation, Western Hemisphere Region (IPPF/WHR). Her work in public health, both domestic and international, has primarily focused on sexual and reproductive health, HIV/STI prevention and sexuality.

At the time that this article was being written, Elizabeth Leitman was an independent consultant in international women's reproductive health; she is currently the Assistant Program Officer for Latin America at the International Women's Health Coalition.

Mahmoud Fathalla is the Associate Director, Population Sciences Division at the Rockefeller Foundationa and a Professor of Obstetrics and Gynecology at Assuit University, Egypt.

\section{Quality/Calidad/Qualité Advisory Committee}

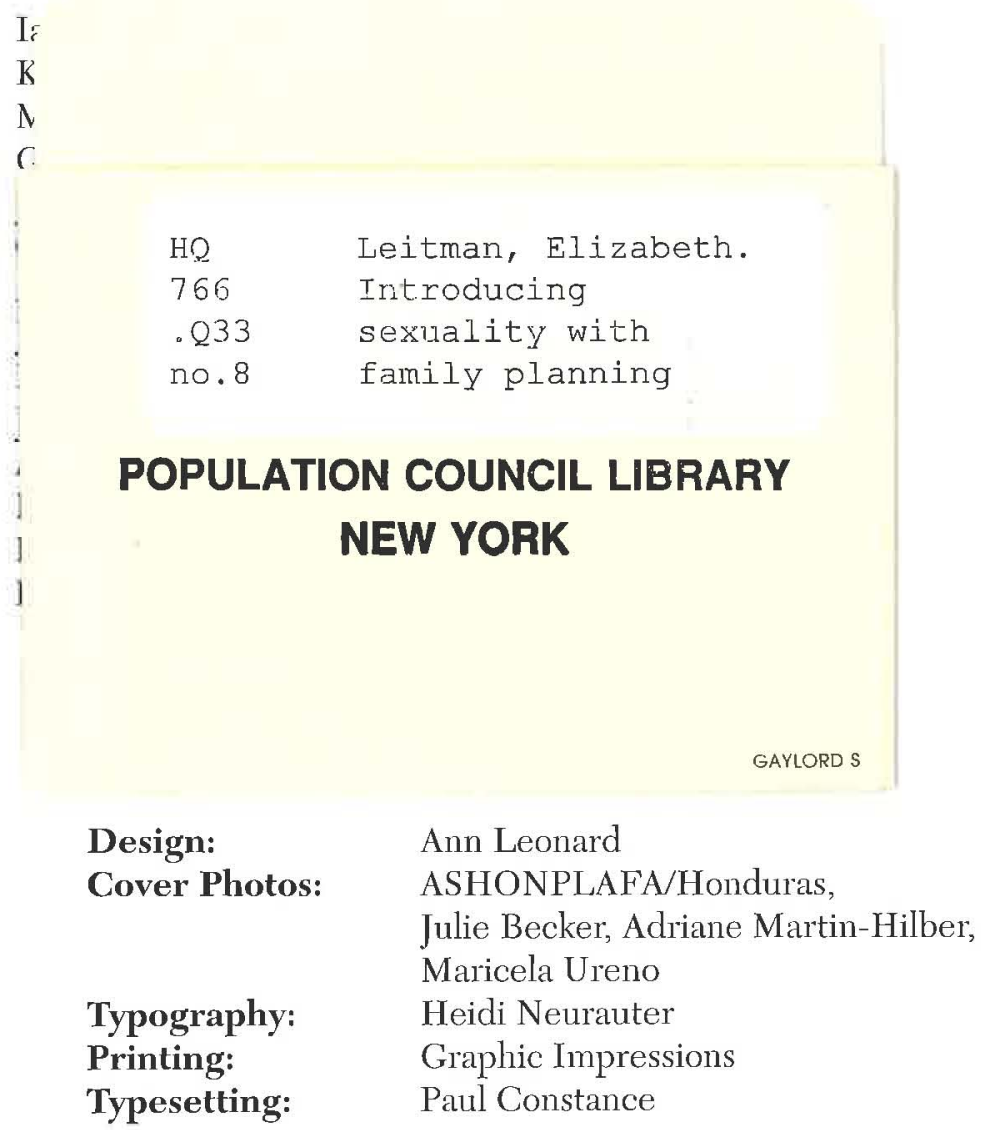

We invite your comments and your ideas for projects which might be included in future editions of Quality/Calidad/Qualité. If you would like to be included on our mailing list, please write to Ann Leonard, Quality/Calidad/Qualité, The Population Council, One Dag Hammarskjold Plaza, New York, N.Y. 10017, U.S.A. 